\title{
Audit Retendering and Mandatory Auditor Rotation
}

August 23, 2019

\begin{abstract}
Building on an auction model, we examine the economic consequences of audit retendering, under which the incumbent auditor in auction possesses both an information advantage and knowledge advantage over outside auditors. Audit retendering allows the firm to retain the incumbent auditor with positive probability, but expect to pay information rent to the incumbent auditor due to his information advantage over outside auditors. In equilibrium, auditor switching (or no switching) under audit retendering conveys additional information to investors, and therefore the informativeness of the audit report under audit retendering is always greater than that under mandatory auditor rotation. We identify conditions under which client firms may benefit from audit retendering. Our findings shed light on the recent European Union Audit Reform, which adopts audit retendering as an alternative to auditor rotation, and have implications to the Public Company Accounting Oversight Board, which are evaluating the proposed mandatory auditor rotation.
\end{abstract}

Keywords: Audit retendering; Auditor rotation; Audit fee; Audit quality; EU Audit Reform JEL Classification: M41, M48 


\section{Introduction}

Empirical evidence shows that the client-auditor relation tends to be long. ${ }^{1}$ The regulators are concerned that long client-auditor relation impedes the audit market competition and may lead to a familiarity threat that erodes the auditor independence. Most prior research, however, does not find evidence that audit firm independence decreases over longer tenure, and some even find that long tenure improves audit quality (Defond and Zhang, 2014). Mandatory auditor rotation, as a solution to improve the auditor independence by cutting the long tenure abruptly, has been subject to critiques of losing client-specific knowledge from prior engagements after an auditor switching (Reid and Carcello, 2017). ${ }^{2}$ This knowledge deficiency hampers a new auditor's effectiveness of audit processes and may result in a deadweight loss to society (GAO, 2003) or impair corporate investment efficiency (Lu and Sivaramakrishnan, 2010). In the U.S., after issuing the concept release on mandatory auditor rotation in 2011, the Public Company Accounting Oversight Board (PCAOB) encountered fierce resistance from companies, auditors, and legislators, and eventually abandoned its auditor rotation project. ${ }^{3}$

While enhancing auditor independence and audit quality remains as the primary concern for the regulator, it is not clear whether mandatory auditor rotation is the best mechanism to achieve these objectives. One interesting recent development is that some regulators have proposed audit retendering to promote effective competition in the audit market. ${ }^{4}$ The U.K. Competition Commission has mandated an order, effective on January 1, 2015, that requires FTSE 350 companies to

\footnotetext{
${ }^{1} \mathrm{~A}$ recent study shows that in 2012 about $25 \%$ of FTSE 350 companies have the same auditor for more than 20 years and $50 \%$ of FTSE 350 companies have the same auditor for more than 10 years. See "Developments in Audit 2018" issued by U.K. Financial Reporting Council.

${ }^{2}$ Reid and Carcello (2017) find that as a new auditor may not retain client-specific knowledge, the market reacts negatively (positively) to events contemplated by the PCAOB between 2011 and 2013 that increased (decreased) the likelihood of rotation. $\mathrm{PwC}$ argues that mandatory auditor rotation will impair audit quality due to disruptive changes and the loss of knowledge ( https://www.pwc.com/gx/en/audit-services/publications/assets/pwcpointofview-mandatoryrotation.pdf).

${ }^{3}$ In June 2013, the U.S. House of Representatives overwhelmingly passed a bill to prohibit the Public Company Accounting Oversight Board (PCAOB) from implementing mandating audit firm rotation (See Cohn, 2013). PCAOB chairman James Doty claimed in 2014 that, "We don't have an active project or work going on within the board to move forward on a term limit for auditors" (http://blogs.wsj.com/cfo/2014/02/05/pcaobs-auditor-rotation-project-isessentially-dead/).

${ }^{4}$ In Appendix I, we present two real-world examples of audit tendering: GlaxoSmithKline in the U.K. and PPL corporation in the U.S. Most U.K. firms report similar audit tendering processes as GlaxoSmithKline.
} 
retender their audits every 10 years. ${ }^{5}$ The European Union (EU) allows the period of mandatory auditor rotation to be extended to 20 years if the audit engagement is retendered or put out to bid at the end of 10 years (Tysiac, 2014) ${ }^{6}$ Several other countries have also enforced audit retendering. ${ }^{7}$

Given that prior research on mandatory auditor rotation has primarily focused on whether the regulation helps improve the auditor independence, the introduction of mandatory auditor retendering brings a new angle to examine the regulation and economic trade-offs to shorten the audit tenure through auditor retendering. An obvious advantage of auditor retendering over mandatory auditor rotation is the possibility of retaining the incumbent auditor's knowledge advantage. ${ }^{8}$ But more importantly, auditor retendering does not necessarily suffer from the auditor independence problem. As pointed out by Defond and Zhang (2014), the regulators are concerned about the "perceived threats" to the auditor independence. Under auditor retendering, the incumbent auditor is retained through a competitive tendering process, which makes it harder for the firm to bring credible threat or pressure to the auditor to compromise audit opinions if such a retendering mechanism is in place. Laura Carstensen, Deputy Chairman of the U.K. Competition Commission, argued "more frequent tendering will ensure that companies make regular and well informed assessments of whether their incumbent auditor is competitive and will open up more opportunities for other firms to compete. A more dynamic, contestable market will reduce the dangers that come with over familiarity and long, unchallenged tenures." 9

In this paper, we analytically model audit retendering using an auction model with information asymmetry between incumbent and entrant (outside) auditors, and compare with a model

\footnotetext{
${ }^{5}$ The full name of the order is "The Statutory Audit Services for Large Companies Market Investigation (Mandatory Use of Competitive Tender Processes and Audit Committee Responsibilities) Order 2014." See full details of the final report at https://www.gov.uk/cma-cases /statutory-audit-services-market-investigation.

${ }^{6}$ Horton et al. (2018) find that investors react positively to the proposals leading the EU Audit Reform.

${ }^{7}$ Outside the EU, China also has a policy, albeit on a smaller scale, that features both retendering and rotation in state-owned financial companies. In August 2010, the Ministry of Finance in China announced that state-owned financial companies must reselect an auditor once every three years through a tender process, and stipulated that the same audit firm cannot be used for more than five straight years. http://english.caixin.com/2012-08-27/100429155.html.

${ }^{8}$ During the PCAOB's public meeting on auditor independence and audit firm rotation on October 18, 2012, Mark Nelson, Professor at Cornell University, stated that, "An advantage of retendering is that clients could choose to retain auditors if they believed the auditor had a particular knowledge advantage."(https://pcaobus.org/Rulemaking/Docket037/ps_Nelson.pdf)

${ }^{9}$ http://www.internationalaccountingbulletin.com/news/no-mandatory-audit-firm-rotation-but-five-year-auditretendering-for-uk-ftse350-cc/.
} 
of mandatory auditor rotation. Thus we offer fresh insights into understanding the outcomes of audit engagement under auditor retendering. For example, to what extent could audit knowledge be retained via audit retendering? How does the audit retendering affect audit quality and the informativeness of audit report? What are the effects on audit fees and audit quality upon switching to an outside auditor under auditor retendering? What are the economic trade-offs between auditor retendering and mandatory auditor rotation regimes? To our knowledge, there has been no prior study in the extant literature that examines the theoretical framework of auditor retendering, and analyzes economic tradeoffs of auditor retendering and mandatory auditor rotation regimes directly.

Specifically, we consider a model with three sets of risk neutral players: a client firm, auditors, and prospective investors of the firm. The client firm expects to issue financial statements that must be audited by one auditor. Events unfold in the following sequence. A firm seeks to raise equity capital to finance a project by selling a portion of the project's payoff to outside investors. After the audit engagement, an auditor exerts effort and issues an audit report about the state of the project. The marginal cost of the audit effort depends on the firm's control risk, which is only observable to the engaged auditor after conducting the audit planning. ${ }^{10}$ The project is funded only if the audit report is good. The auditor's report contains a type-II error - a bad state may not be detected by the auditor. After observing the auditor's good report, investors require a fraction of the project return to break even. Investors receive their share of the cash flows if the project succeeds, otherwise investors receive zero.

There are two types of auditors in the market: an incumbent auditor who has prior engagement with the client firm, and an entrant auditor with no prior engagement. The incumbent and entrant auditors differ from two distinctive sources. First, the incumbent observes the client firm's control risk through prior experience with the client firm, whereas the entrant auditor knows only the dis-

\footnotetext{
${ }^{10}$ According to SAS No.107 (AICPA, 2006), control risk refers to the risk of a material misstatement in the financial statements arising to the absence or failure in the operation of relevant controls of the entity. Firms must have sufficient internal controls in place to prevent and detect instances of fraud and error. When the audit entity does not have adequate internal controls to prevent and detect instances of fraud and error in the financial statements, control risk is considered to be high.
} 
tribution. Thus there exists information asymmetry between the incumbent and entrant auditors. We refer to this difference as the incumbent auditor's information advantage. Second, the incumbent auditor possesses firm-specific knowledge learned from the prior engagement, which lowers his marginal cost of auditing a high-risk firm. We refer to this as the incumbent auditor's knowledge advantage. We assume that the audit market is competitive, and thus the entrant auditor without information or knowledge advantage earns zero profit.

The bidding game follows the standard first-price bidding with asymmetrically informed bidders (Engelbrecht-Wiggans et al., 1983). Both the informed incumbent and uninformed entrant auditors submit sealed bids to compete for the audit engagement, and the firm accepts the lowest bid. In equilibrium, both bidders randomize their bids over the range between the expected audit cost and the maximum audit cost for the entrant. The entrant earns zero profit on average, while the incumbent earns strictly positive profit (information rent) because of his information advantage and knowledge advantage. On average, the audit fee from the outside auditor is lower than that from the incumbent auditor.

In equilibrium, a high-control-risk client firm is more likely to switch to the outside auditor than a low-control-risk firm: observing a switch under audit retendering conveys information to investors about the firm's unobservable control risk. Therefore the informativeness of the report issued by the incumbent auditor is higher than that issued by the outside auditor, because the investors perceive that the firm's control risk is more likely to be high (and hence a greater typeII error) given auditor switching, and that the outside auditor's audit quality is lower than the incumbent due to knowledge deficiency in the high-control-risk firm. The investors thus request a lower fraction when observing the good report from the incumbent auditor than from the outside auditor. Interestingly, our analytical results are supported by recent empirical evidence by Hallman et al. (2018) that competitive bidding improves incumbent auditors' audit quality proxied by the likelihood of subsequent financial restatements.

Our model highlights the cost and benefit of competitive tendering process when auditors are asymmetrically informed about the client firm's control risk at the time of bidding. The regulators, 
who intend to introduce audit retendering to break the long tenure and promote audit market competition, need to be aware of the nature of the tendering process. That is, the audit retendering process cannot achieve perfect competition, simply because incumbent auditors inevitably gain information advantage over outside auditors that allow them to obtain positive information rent. Thus we focus on the economic trade-off between the knowledge retention and information rent under audit retendering, and compare those trade-offs with mandatory auditor rotation regime.

Under mandatory auditor rotation, the incumbent auditor is not allowed to compete for the next-period engagement; an entrant auditor makes an offer that covers the expected costs and earns zero profit in a competitive audit market. As the incumbent cannot continue the audit engagement with the client firm, the expected audit quality by the entrant auditor is always lower than that of the incumbent, hence reducing investment efficiency. Furthermore, because the auditor switch conveys information about the firm's risk, the incumbent auditor's report under the audit retendering regime is more informative than the auditor report issued under the mandatory rotation regime; whereas the entrant auditor's report is less informative than the one issued under the mandatory rotation regime.

In terms of the expected audit fee and the audit report informativeness under two regimes, we also find interesting results. On the one hand, the expected audit fee is always lower under mandatory auditor rotation than under auditor retendering, due to the information rent earned by the incumbent auditor in the latter regime. On the other hand, the average auditor report informativeness under audit retendering is always higher than that under mandatory auditor rotation, due to the incumbent auditor's higher audit quality from his knowledge advantage. The client firm's expected payoff depends on the expected audit fee and the investment loss due to the auditor's type-II error. Thus, in comparing these two regimes, the economic trade-off depends on information rent and audit efficiency. We show that the client firm is better off under audit retendering, when the incumbent's knowledge advantage is more important, or when the incumbent's information advantage (rent) is less costly.

In our model, we focus on the economic tradeoffs between information rent and client-knowledge 
retention under these two regimes. Though we do not explicitly model the auditor independence under auditor retendering, we point out that auditor retendering, with its advantage of potentially retaining client-specific knowledge, does not necessarily suffer the independence problem because the auditor is selected through a competitive tendering process. In our model, information rent under auditor retendering comes from asymmetric information among bidders and is therefore inevitable, as long as the incumbent auditor is allowed to participate in the audit tender. The firm, without observing the control risk, accepts the lowest bid from the auditors and switches only when an outside auditor bids a lower price than the incumbent. Thus, client firms cannot use information rent as a credible threat to terminate the audit service to induce compromisation, different from the incumbent rent from fixed known switching cost in DeAngelo (1981). We provide some discussion about the problem in the last part.

To the best of our knowledge, our paper is the first study to formally analyze the auditor retendering provisions in the EU Audit Reform. We contribute to the extant auditor rotation literature by introducing this new retendering feature to academic discussions. Our theoretical characterization of audit retendering regime and its comparison with mandatory auditor rotation regime generates testable empirical hypotheses for EU firms. Our model predicts that under auditor retendering, both audit fee and audit quality upon auditor switching are lower than the ones without auditor switching, and these results are driven by both information and knowledge advantages of the incumbent auditor over the outside auditor. Our model also predicts that, client firms are more likely to benefit from audit retendering than mandatory auditor rotation when they are more homogeneous in terms of control risk, when they have higher control risk, when the size of investment is larger, or when incumbent auditors have industry or geographical expertise in auditing the client firms. Conditional on the size of investment, a firm's expected payoff under audit retendering is higher than under auditor rotation when legal liability is high.

Our paper also has policy implications, as the model we develop not only provides useful feedback regarding the EU Audit Reform, but also sheds light on the related PCAOB deliberations in the U.S. If the regulator concerns equally about the client firm's and the auditor's payoffs, then 
the auditor retendering regime strictly dominates the mandatory auditor rotation regime. This is because information rent simply represents a surplus split between the client firm and the auditor and does not affect the social welfare, while the audit quality under the auditor retendering regime is strictly higher than the mandatory rotation regime. Otherwise, if the regulator cares more about the client firm's payoff, then mandatory auditor rotation may be beneficial especially when information rent is very costly to the client firm. These results may shed light on the PCAOB's decision in whether or not to adopt mandatory auditor rotation or consider alternative mechanisms like audit retendering in the U.S.

The rest of the paper is organized as follows. Section 2 discusses related studies in the literature. Section 3 presents the structure and ingredients of the model. Section 4 analyzes the equilibrium under the audit retendering regime. Section 5 establishes the equilibrium audit quality and audit fees under the mandatory auditor rotation regime. Section 6 compares the two regimes. Section 7 discusses auditor independence and other related issues, and Section 8 concludes. We relegate all proofs to Appendix II.

\section{Related Literature}

In this section, we review four strands of literature and discuss how our paper fits into each strand. The first strand has paid much attention to mandatory auditor rotation. By contrast, we focus on audit retendering, a new provision in the EU audit reforms. This key feature distinguishes our paper from related studies on mandatory auditor rotation. Lu and Sivaramakrishnan (2009) studied the interaction between auditor rotation and opinion shopping, and showed that when firms engage in opinion shopping, mandatory auditor rotation may impair investment efficiency. By contrast, Dordzhieva (2018) showed that mandatory rotation could actually impair auditor independence, because mandatory rotation weakens the disciplining effect of auditor tenure, and therefore provides auditors with an opportunity to discipline an auditor's decision to accommodate a client, thereby ironically making the initial decision to compromise independence comparatively less costly. Dopuch et al. (2001) showed that mandatory auditor rotation decreases investment in 
an experimental setting. Empirically, Kwon et al. (2014) suggested that mandatory audit firm rotation increases the cost for audit firms and clients, while having no discernable positive effect on audit quality. Cameron et al. (2016) observed results consistent with an increase in audit quality perception prior to mandatory auditor rotation. Gerakos and Syverson (2015) estimated that for U.S. publicly traded firms, mandatory audit firm rotation would induce consumer surplus losses of approximately $\$ 2.7$ billion if rotation were required after 10 years and $\$ 4.7-5.0$ billion if after only four years. Inspired by the recent EU audit reforms, we take a different approach by examining a substitute regime of audit retendering. Relative to auditor rotation, audit retendering can result in higher audit fees but more informative audit reports. Thus, our study adds to the literature by showing that audit retendering may be a credible alternative to auditor rotation and by identifying the conditions under which client firms may benefit from audit retendering. ${ }^{11}$ To our knowledge, there have been no empirical studies on the economic consequences of audit retendering.

The second strand is related to auditor tenure. Conducted in countries with only voluntary auditor switches, these studies generate indirect inferences pertaining to mandatory auditor rotation. Johnson and Lys (1990) argued that auditors obtain competitive advantages through specialization, and clients can lose client-specific knowledge if they change auditors. Consistent with this intuition, lawsuits against auditors and fraudulent financial reporting have been found to be more likely during early periods of auditor tenure (St. Pierre and Anderson, 1984; Carcello and Nagy, 2004). In addition, longer audit tenure is found to mitigate extreme earnings manipulations (Johnson et al., 2002; Myers et al., 2003; Ghosh and Moon, 2005; Chen et al., 2008), to lower the cost of borrowing (Mansi et al., 2004), and to reduce acquiescence to the client (Bamber and Iyer, 2007). Taken together, these studies imply that mandatory auditor rotation may be detrimental to audit quality due to the loss of client-specific knowledge. In our model, since the incumbent auditor may win the audit engagement, audit retendering may preserve valuable client-specific knowledge, thus overcoming the main weakness associated with mandatory auditor rotation.

The third strand of literature analyzes competition among audit firms. Our paper focuses on

\footnotetext{
${ }^{11}$ Specific empirical implications are provided in Section 4.4 .
} 
analyzing a competitive bidding model in the presence of asymmetric information between the incumbent and entrant auditors. The bargaining power of the incumbent auditor is endogenously determined by the competition from an uninformed bidder. The focus on audit retendering distinguishes our paper from the extant literature. Simunic (1980) explained that the effect of monopoly pricing on observable audit fees depends on the price elasticity of demand implicit in the client's cost minimization problem. DeAngelo (1981) developed a simple multi-period (perpetuity) audit pricing model and argued that low-balling arises because switching cost allows auditors to charge "quasi-rents" on continuing engagements. Dye (1991) argued that low-balling exists because these quasi-rents cannot be fully disclosed. Magee and Tseng (1990) showed that the auditor's value of incumbency presents a threat to independence only under limited circumstances. Specifically, when auditors have all bargaining power, client firms have nothing to gain by threatening termination of incumbent auditors. Kanodia and Mukherji (1994) argued that low-balling may arise from a combination of the auditor's private information and switching costs. Gigler and Penno (1995) argued that cost differences among auditors can be a source of economic rents to the incumbent auditor. Such imperfect competition may induce clients to underinvest in their accounting systems and to accept the incumbent auditor's management advisory service, even if a rival auditor submits a lower bid. Morgan and Stocken (1998) found that equilibrium audit fees may not fully reflect a client's business risk, because auditors can learn about the business risk associated with the client over the course of the audit engagement.

The fourth strand examines the economic impact of auditor liability on a firm's investment decisions (e.g., Antle and Nalebuff, 1991; Schwartz, 1997; and Lu and Sapra, 2009). These papers typically model a capital market valuation rule, an auditor's attestation strategy, and a client firm's investment decision. In these papers, because there is no information asymmetry, the auditor's role is not to verify a firm's strategic report, but rather to identify the nature of the firm's operational activities. Naturally, the equilibrium investment level depends on a firm's audit fees/liability ratio. A low fee-to-liability ratio makes an auditor more conservative, which, in turn, reduces audit quality and therefore decreases investment efficiency. Similarly, Laux and Newman (2010) analyzed the 
effect of auditor liability on client acceptance. In their setting, the source of potential over- or under- investment is the auditor's moral hazard problem with respect to the client evaluation task. By contrast, we model a capital market valuation in the presence of information asymmetry between incumbent and entrant auditors. Audit retendering affects auditors' attestation efforts, and thus investors' valuation rule.

\section{The Model}

We consider a one-period model with three sets of risk neutral players: a client firm, auditors, and prospective investors At date 0, the firm seeks to raise capital $K$ to start a project by selling an $\alpha$ $\in[0,1]$ proportion of the project's payoff to outside investors. The project has two possible states $i \in\{G, B\}$. With a probability $p \in(0,1)$, the project state is good and generates a return (cash flow) of $R$, whereas with a probability $1-p$, it is a bad project and yields zero future return. The project state $i \in\{G, B\}$ is independent and identically distributed in each investment period. The probability $p$ is common knowledge. We further assume that $p R>K$ so that investors would invest in the project in each period without knowing the project state.

Neither the firm nor investors can observe the project state, but the firm can hire an auditor to issue an audited report with respect to the project state - audited financial statements - before raising capital from investors. The firm pays the auditor a non-contingent fee, denoted as $F$, for the audit service. After the auditor becomes engaged, he proceeds to conduct the audit by choosing an unobservable audit effort $q \in(0,1]$ and obtains a binary signal $j \in\{g, b\}$ about the project state. We assume that the auditor makes no mistake in detecting a good project (i.e., there is no type-I error), however, he may fail to detect a bad project depending on his audit effort (i.e., there may be a type-II error). ${ }^{12}$ The level of audit effort $q$ determines the audit quality, as represented by the type-II error of the audit report. Specifically, we have

$$
\operatorname{Pr}(b \mid B)=q, \quad \operatorname{Pr}(g \mid G)=1 .
$$

\footnotetext{
${ }^{12}$ A similar audit technology was assumed in Dye (1993, 1995), Schwartz (1997), Chan and Pae (1998), Hillegeist (1999), Radhakrishnan (1999), Chan and Wong (2002), and Ye and Simumic (2010).
} 
Thus, although a bad audit report is perfectly informative about the project's bad state, a good audit report is a noisy signal about the project's good state. An increase in the audit quality $q$ reduces the type-II error in the audit report.

The audit effort cost depends on the auditor type and the control risk of the client. As a prior, the control risk $(r)$ can be either high $(r=h)$ with an ex-ante probability $\lambda \in(0,1)$, or low $(r=l)$ with a probably $1-\lambda$. A client firm's control risk does not change throughout the audit engagement, but it is unknown to both the firm and the auditor prior to the audit engagement. ${ }^{13}$ However the auditor can perfectly observe the true control risk during an audit engagement. ${ }^{14}$ After the engagement, an auditor will conduct audit planning, which ensures that appropriate attention is devoted to important areas and potential problems are promptly identified, and that audit work is completed expeditiously and properly coordinated. Thus, any engaged auditor can perfectly observe the client's control risk $r$ through audit planning before actually exerting audit effort.

There are two types of auditors in the market who compete for the audit service of the current period: an incumbent (inside) auditor and an entrant (outside) auditor from the competitive audit market. The incumbent auditor is the existing auditor who has performed the audit service in the previous period, which we do not model. The incumbent has already observed the firm's control risk before engaging, while the outside auditor cannot.

Besides the informational advantage, the incumbent auditor also gains firm-specific knowledge or expertise that allows him to conduct the audit more efficiently. We use $C(q, r, a)=c_{r}^{a} \psi(q)$ to denote the cost of the audit effort for a type $a$ auditor engaging in a firm with control risk $r$, where $a \in\{I, O\}$ indicates the auditor's type being either an incumbent $(I)$ or an outside entrant auditor $(O)$, and $q$ is the audit effort level. The first part of the audit effort cost represents the marginal cost of audit effort $c_{r}^{a}$, which differs across different types of auditors for firms with different control risks. The second part $\psi(q)$ represents the audit production cost when exerting effort $q$. We make

\footnotetext{
${ }^{13}$ The assumption that the firm has no private information is common in the auditing literature; see for example, Dye (1993, 1995), Schwartz (1997), Chan and Pae (1998), Chan and Wong (2002), Laux and Newman (2010) and Lu and Sapra (2009).

${ }^{14}$ See also Kanodia and Mukherji (1994). In Section 7, we discuss the case in which an entrant auditor may ex ante be partially informed about the client's control risk either through financial statements or from prior industry experience.
} 
the following standard assumptions about $\psi: \psi(0)=0, \psi^{\prime}>0$ (but $\left.\psi^{\prime}(0)=0\right), \psi^{\prime \prime}>0$, and $\psi^{\prime \prime \prime}=0$. For simplicity, we adopt a quadratic function $\psi(q)=q^{2} / 2$, which is commonly used in the literature and satisfies all of the aforementioned assumptions. ${ }^{15}$ The marginal cost of audit effort $c_{r}^{a}$ satisfies the following condition:

$$
c_{l}^{O}=c_{l}^{I}<c_{h}^{I}<c_{h}^{O}
$$

That is, when the control risk is low, the incumbent and entrant auditors both incur the same audit cost $-c_{l}^{I}=c_{l}^{O} \equiv c_{l}$. When the control risk is high, it is more costly to conduct the audit for both types of auditors, and even more so for the entrant auditor $-c_{l}<c_{h}^{I}<c_{h}^{O} \equiv c_{h}$. This assumption implies that when the control risk is high due to high complexity of accounting transactions, it is less costly for the incumbent auditor to conduct the audit than the entrant auditor, due to the knowledge learning from prior experience with the client firm. We call this the "knowledge advantage" of the incumbent auditor. However, when the control risk is low, the incumbent auditor has no advantage over the entrant auditor. ${ }^{16}$

An audit failure occurs if the auditor does not detect material misstatements in the financial statements - if the auditor issues a good report $g$ upon a bad project state $B$. In case of an audit failure, the firm goes bankrupt and is unable to pay any damage to investors, and investors sue the auditor. The auditor's possible legal costs may include a damage penalty to investors and litigation costs through the court, legal fees, and opportunity costs of time spent in court. ${ }^{17}$ We denote the auditor's litigation cost when a type-II audit failure occurs by $L$. For simplicity, we normalize the

\footnotetext{
${ }^{15}$ See Chan and Pae (1998) and Laux and Newman (2010).

${ }^{16}$ Our goal is to highlight the economic effects of the incumbent's knowledge advantage. It is plausible that the incumbent may also have knowledge advantage when the control risk is low. The economic trade-off documented herein is not affected by this assumption and the results are qualitatively unchanged.

${ }^{17}$ We assume investors can sue the auditor but not the firm. We adopt this assumption for two reasons. First, this assumption simplifies the analysis, permitting us to avoid questions of how to divide damage payments between a firm and its auditor. In addition, it makes the signaling problem more significant because the court system cannot directly punish a firm for lying. However, because the audit fee is determined competitively, it will reflect any expected damage payment; thus, ex ante, the auditor's expected utility does not depend on the way damages are assigned. Further, we assume penalties are imposed on the auditor but not on the firm. In general, although both the auditor and firm are subject to penalties if the auditor does not detect misstatements, in an audit failure, the firm is often bankrupt, whereas the auditor has "deep pockets." Assuming penalties on the auditor but not the firm is an extreme case capturing this differential ability to pay the penalty. This assumption is not uncommon in the literature (see, e.g., Dye (1993, 1995), Chan and Pae (1998), and Schwartz (1997), and Laux and Newman (2010)).
} 
damage penalty to zero, and thus the investors in our model do not receive any part of $L .{ }^{18}$ We also assume the audit litigation $\operatorname{cost} L$ is not too large, such that the audit effort $q$ is smaller than one in equilibrium. ${ }^{19}$

\section{Audit Retendering}

In this section, we consider the case in which the client firm is required to retender its audit engagement for each period. We consider a single-period model, assuming that the auditor engaged in the prior period always participates in the tendering process for the next period's audit service. As such, there are two types of auditors in the audit retendering process: the existing incumbent (inside) auditor and a representative entrant (outside) auditor from the competitive audit market. The incumbent auditor can perfectly observe the control risk by learning through the prior audit engagement with the client firm, while the entrant auditor cannot observe the control risk and only knows the prior distribution of the control risk $\lambda$. Hence the incumbent auditor has both an informational advantage and a knowledge advantage over the entrant auditor.

The timing of the events is as follows.

- Date 1: the incumbent and entrant auditors simultaneously submit a sealed bid (stated as an audit fee) to the client firm based on their own information sets. The firm accepts the lower bid between the two offers and initiates the audit engagement. ${ }^{20}$

- Date 2: the engaged auditor chooses the audit effort and issues an audit report.

- Date 3: investors observe the auditor's report as well as the auditor's type - whether an auditor switch has occurred through the retendering process. If the audit report is $b$, the project is not funded and the game ends. Only when a good report $g$ is issued are investors

\footnotetext{
${ }^{18}$ Our assumption is consistent with prior literature that shows the damage payment has no direct effects on the audit effort (Laux and Newman, 2010). Our analysis does not change if we allow investors to receive a non-zero penalty payment from the auditor.

${ }^{19}$ The exact conditions will be presented in Section 5 .

${ }^{20}$ In practice, because of the heterogeneity among auditors, firms may consider other factors, such as industry experience and capacity of the proposed audit team, to select a new auditor. Please refer to the discussion in Section 7 .
} 
willing to provide the capital through shares of the project's return. The project is funded by selling $\alpha_{a}$ share of the firm to investors.

- Date 4: provided that the project is funded, the cash flow is realized. In case of success, investors receive an $\alpha_{a}$ portion of the cash flow $R$. In case of failure, investors receive zero.

\subsection{The Bidding Game}

We now solve the auditor's bidding game on Date 1. The bidding game follows the standard firstprice bidding with asymmetrically informed bidders (Engelbrecht-Wiggans, et al., 1983). To obtain the equilibrium bidding strategies, we note that the bid submitted by each type of auditor should at least cover their expected cost - the audit liability sum the cost of audit effort. Hence before solving the bidding game, we need to solve backwards each auditor's optimal effort after winning the engagement on Date 2 .

The winning auditor's problem. On Date 2, the winning auditor perfectly observes the control risk of the client firm after the audit engagement, and chooses effort $q_{r}^{a}, a \in\{I, O\}$, to maximize the expected payoff. For any given bid $F$, the winning auditor's expected payoff is given by $F-w_{r}^{a}(q)$, where $w_{r}^{a}(q)$ is the expected total audit cost for the client firm with the control risk $r \in\{l, h\}$. The total audit cost $w_{r}^{a}(q)$ is the cost of audit effort plus the expected litigation cost. The cost of effort depends on the control risk $r \in\{l, h\}$ and on the type of the auditors $a \in\{I, O\}$. A litigation cost is only incurred when a type-II error exists. Therefore, the expected total audit cost is

$$
w_{r}^{a}(q)=(1-q)(1-p) L+c_{r}^{a} \psi(q) .
$$

Thus, the auditor chooses the optimal effort by solving the following problem:

$$
\begin{aligned}
q_{r}^{a} & \in \underset{q}{\operatorname{argmax}} F-(1-q)(1-p) L-c_{r}^{a} \psi(q), \\
\Rightarrow q_{r}^{a} & =\frac{(1-p) L}{c_{r}^{a}} .
\end{aligned}
$$

Recall the assumption in (2), $c_{l} \equiv c_{l}^{O}=c_{l}^{I}<c_{h}^{I}<c_{h}^{O} \equiv c_{h}$, that is, the incumbent auditor has a 
lower marginal cost than the entrant in conducting the audit service for the high-risk client firm, but not for the low-risk client. It is intuitive to see that $q_{l}^{O}=q_{l}^{I}>q_{h}^{I}>q_{h}^{O}$. The incumbent auditor's optimal effort is strictly higher than the entrant's when auditing the high-risk client firm. Given the equilibrium audit effort $q_{r}^{a}$, the type- $a$ auditor's total cost of audit engagement for the client with risk $r$ is given by $w_{r}^{a}=\left(1-q_{r}^{a}\right)(1-p) L+c_{r}^{a} \psi\left(q_{r}^{a}\right)$. To simplify notations, we define the entrant's expected audit cost $w_{l} \equiv w_{l}^{O}$ and $w_{h} \equiv w_{h}^{O}$. Note that the incumbent's expected audit cost is $w_{l}^{I}=w_{l}$ for the low-risk client and is $w_{h}^{I}$ for the high-risk client, where $w_{l}<w_{h}^{I}<w_{h}$. Denote by $\bar{w}$ the entrant auditor's expected total cost prior to the audit engagement, which represents the minimum audit fee that the entrant auditor, not observing the true control risk, is willing to bid in order to break even, and we have $\bar{w} \equiv \lambda w_{h}+(1-\lambda) w_{l}$.

The auditors' bidding problem. We are now ready to solve the equilibrium bidding strategies of the incumbent and entrant auditors on Date 1. Let $G_{O}(F)$ denote the cumulative distribution function (c.d.f) of the bid $F_{O}$ from the uninformed entrant auditor, and $G_{I}^{r}(F)$ denote the c.d.f. of the bid $F_{I}^{r}$ from the informed incumbent auditor. The uninformed entrant auditor, without observing the firm's control risk, maximizes her overall expected payoff given the bidding strategy of the incumbent,

$$
U_{O}(F)=\lambda \int\left(1-G_{I}^{h}(F)\right)\left(F-w_{h}\right) g_{O}(F) d F+(1-\lambda) \int\left(1-G_{I}^{l}(F)\right)\left(F-w_{l}\right) g_{O}(F) d F
$$

where $w_{r}$ is the expected audit cost for the entrant auditor for the firm with the control risk $r$. The entrant auditor wins the bid whenever the bidding price $F$ is below the incumbent's bid, which follows a distribution of $G_{I}^{r}($.$) . Thus, the probability that the entrant auditor wins is given by$ $\operatorname{Pr}\left(F_{I}^{r}>F\right)=1-G_{I}^{r}(F)$ in the firm with the control risk $r$. When bidding any price $F$, the entrant auditor's payoff is given by the probability of winning at a price $F$ multiplied by the audit fee minus the expected audit cost $w_{r}$ (i.e., $F-w_{r}$ ). We then take the expectation of the payoff over the entire bidding range of her strategy, which we will discuss later, and obtain the payoff function in $(4)$.

By contrast, the incumbent auditor observes the control risk $r$ and maximizes his expected 
payoff in each type of firm given the entrant's bidding strategy. The incumbent's payoffs are given by, respectively,

$$
\begin{aligned}
U_{I}^{h}(F) & =\int \operatorname{Pr}\left(F_{O}>F\right)\left(F-w_{h}^{I}\right) g_{I}^{h}(F) d F, \\
U_{I}^{l}(F) & =\int \operatorname{Pr}\left(F_{O}>F\right)\left(F-w_{l}\right) g_{I}^{l}(F) d F,
\end{aligned}
$$

where $\operatorname{Pr}\left(F_{O}>F\right)$ is the probability of winning the bidding and $F-w_{r}^{I}$ reflects the profit above the expected audit cost.

The equilibrium bidding strategies. We solve the previous maximization programs by applying the general result from the first-price bidding equilibrium with asymmetrically informed bidders in Engelbrecht-Wiggans et al. (1983). The auditors' equilibrium bidding strategies under asymmetric information are characterized in Lemma 1.

Lemma 1 (i) No equilibrium exists in pure strategies; (ii) the uninformed entrant-auditor randomizes her bid according to:

$$
G_{O}(F)=\left\{\begin{array}{cc}
0 & \text { where } 0<F<\bar{w} \\
\frac{F-\bar{w}}{F-w_{l}} & \text { where } \bar{w} \leq F<w_{h} \\
1 & \text { where } w_{h} \leq F<\infty
\end{array}\right. \text {; }
$$

(iii) when the control risk is low, $r=l$, the informed incumbent auditor randomizes his bid according to

$$
G_{I}^{l}(F)=\left\{\begin{array}{cc}
0 & \text { where } 0<F<\lambda w_{h}+(1-\lambda) w_{l} \\
\frac{F-\bar{w}}{(1-\lambda)\left(F-w_{l}\right)} & \text { where } \bar{w} \leq F<w_{h} \\
1 & \text { where } w_{h} \leq F<\infty
\end{array}\right.
$$

(iv) when the control risk is high, $r=h$, the informed incumbent auditor bids $F=w_{h}$ all the time; i.e.,

$$
G_{I}^{h}(F)=\left\{\begin{array}{c}
0 \quad \text { where } 0<F<w_{h} \\
1 \quad \text { where } w_{h} \leq F<\infty
\end{array} .\right.
$$

The bidding range $\left[\bar{w}, w_{h}\right]$ deserves some discussion, which we provide in more detail in the proof of Lemma 1. Both the incumbent and entrant auditors must bid over the same range in order for the mixed-strategy equilibrium to hold. The lower bound $\bar{w}$ is the entrant auditor's expected audit 
fee to break even without any private information about the firm's control risk. The entrant will not bid below $\bar{w}$, because otherwise he will suffer an expected loss, upon winning with a positive probability. The upper bound $w_{h}$ represents the expected total audit costs for the entrant auditor when the control risk is high. It is the entrant's maximum bid for two reasons: (1) if the upper bound falls below $w_{h}$, with a strictly positive probability, the entrant may win for the high-controlrisk firm and suffer a loss, because the fee does not cover her expected audit cost; and (2) if the upper bound exceeds $w_{h}$, the incumbent observing a high control risk can always bid strictly below $w_{h}$ and win the bidding, earning strictly positive profits with a positive probability. Therefore the incumbent has an incentive to deviate by bidding over a range with a lower upper bound. Together, the upper bound of the bidding range shall be exactly $w_{h}$.

Following Engelbrecht-Wiggans, et al. (1983), in such bidding no pure strategy exists, because any pure-strategy bidding puts the entrant auditor at a loss in expectation. ${ }^{21}$ This is because if an entrant auditor were to adopt a pure strategy that could be predicted, the incumbent auditor would always bid a slightly lower audit fee when the control risk is low, and not bid when the control risk is high. The entrant auditor would then win the audit engagement only when the control risk is high, resulting in a winner's curse.

In equilibrium, the entrant, without any information about the client firm, bids according to the mixed strategy $G_{O}(F)$ stated in Lemma 1 to break even on average, $U_{O}(F)=0$. Otherwise, the outside auditor will not participate in the bidding. Notice that to avoid the winner's curse, the outside auditor always bids the upper bound $w_{h}$ with a strictly positive probability density, $g_{O}\left(w_{h}\right)=\left(w_{h}-\bar{w}\right) /\left(w_{h}-w_{l}\right)$. In contrast, the incumbent auditor earns a strictly positive profit (information rent) due to his information advantage. When the control risk is high, the incumbent auditor always bids the upper bound $w_{h}$, which gives him a constant profit upon winning- $U_{I}^{h}(F)=$ $w_{h}-w_{h}^{I} \cdot{ }^{22}$ When the control risk is low, the incumbent auditor plays a mixed bidding strategy over the bidding range $\left[\bar{w}, w_{h}\right]$ and also earns a constant profit, $U_{I}^{l}(F)=\bar{w}-w_{l}=\lambda\left(w_{h}-w_{l}\right)$ as

\footnotetext{
${ }^{21}$ See the Appendix proof for a detail argument of the non-existence of pure-strategy bidding.

${ }^{22}$ In fact, when the control risk is high, perverse equilibria exist for the incumbent to bid in the upper bound range $\left[w_{h}^{I}, w_{h}\right]$. We can use the trembling-hand refinement and find the equilibrium where the incumbent bids $w_{h}$ when the control risk is high. The argument is provided in the proof.
} 
shown in the proof.

\subsection{Audit Fees and Audit Switching}

The expected audit fees. From the firm's perspective, we calculate the ex-ante expected audit fees from an incumbent auditor's engagement vs. an entrant auditor's engagement. We assume that if the incumbent and the outside auditors bid the same price, the incumbent auditor wins the engagement. ${ }^{23}$ The expected audit fee when the incumbent auditor wins the engagement is $E\left[F_{I}\right]=\lambda E\left[F_{I}^{h}\right]+(1-\lambda) E\left[F_{I}^{l}\right]$, where $E\left[F_{I}^{h}\right]$ and $E\left[F_{I}^{l}\right]$ are the expected audit fee of the incumbent auditor winning high- and low-risk firms as below

$$
E\left[F_{I}^{r}\right]=\int_{\bar{w}}^{w_{h}}\left(1-G_{O}(F)\right) F g_{I}^{r}(F) d F
$$

respectively. Substituting the equilibrium bidding strategies, $\left.G_{O}(F)\right)$ and $g_{I}^{r}$, in Lemma 1, we obtain that $E\left[F_{I}^{h}\right]=\lambda w_{h}$ and $E\left[F_{I}^{l}\right]=\lambda w_{h}+\frac{1}{2}(1-\lambda) w_{l}$. Thus, in equilibrium, given the optimal audit effort levels $q_{h}$ and $q_{l}$ chosen by an entrant auditor, we have

$$
E\left[F_{I}^{*}\right]=\lambda w_{h}+\frac{1}{2}(1-\lambda)^{2} w_{l}
$$

Similarly, we calculate the ex-ante expected audit fee from an entrant auditor's engagement.

$$
E\left[F_{O}\right]=\int_{\bar{w}}^{w_{h}}\left[\lambda\left(1-G_{I}^{h}(F)\right) F+(1-\lambda)\left(1-G_{I}^{h}(F)\right)\right] g_{O}(F) d F
$$

Substituting the equilibrium bidding strategies in Lemma 1 and the optimal audit effort levels $q_{h}$ and $q_{l}$, we have

$$
E\left[F_{O}^{*}\right]=\lambda(1-\lambda) w_{h}+\frac{1}{2}(1-\lambda)^{2} w_{l}
$$

From the firm's perspective, the expected audit fee for the incumbent auditor $E\left[F_{I}^{*}\right]$ is higher than that for the entrant auditor $E\left[F_{O}^{*}\right]$. The incumbent auditor's fee premium is driven by the incumbent auditor winning the bid when the firm's control risk is high and charging the highest

\footnotetext{
${ }^{23}$ This is a reasonable assumption, because the firm may need to incur a switching cost that we do not model (see DeAngelo 1981; Kanodia and Mukherji 1994) or the incumbent auditor may provide a higher quality audit due to the knowledge advantage..
} 
fee $w_{h}$, that is, $E\left[F_{I}^{*}\right]-E\left[F_{O}^{*}\right] \equiv \lambda E\left[F_{I}^{h}\right]=\lambda^{2} w_{h}$. The probability that the incumbent wins in the high-risk firm is exactly $\lambda$, because the entrant auditor bids with a mass of $\lambda$ (which is her best guess about the firm risk being high, based on the prior distribution) at the upper bound in order to protect herself from the winner's curse. Thus, if the probability of high control risk $\lambda$ increases, the incumbent auditor is more likely to obtain this premium. It is also interesting to note that the overall ex-ante expected fee from the entrant auditor, $E\left[F_{O}\right]$, is the same as the incumbent auditor's expected fee when winning the engagement in the low-risk firm, $(1-\lambda) E\left[F_{I}^{l}\right]$. Because of information advantage, the incumbent auditor earns informational rent in the low-risk firm, while the entrant auditor simply breaks even across firms with different control risks.

Proposition 1 The expected audit fee for the incumbent auditor is always higher than that for the entrant auditor $E\left[F_{I}^{*}\right]>E\left[F_{O}^{*}\right]$. The difference in the expected audit fee increases in the probability of high control risk $\lambda$ and the entrant's expected audit cost in the high-risk firm $w_{h}$.

Ex-ante, the total expected audit fee for the firm is given by

$$
F_{t}^{*}=E\left[F_{O}^{*}\right]+E\left[F_{I}^{*}\right]=\bar{w}+\lambda(1-\lambda)\left(w_{h}-w_{l}\right) .
$$

We simply add the expected audit fees from the incumbent and entrant auditors together, because $E\left[F_{I}^{*}\right]$ and $E\left[F_{O}^{*}\right]$ already take into account the endogenous outcome of the bidding game (i.e., the probability of switching) in calculating the fee from one auditor. We will subsequently compare the expected audit fees under the mandatory rotation and audit retendering regimes, and explain in more detail about the incumbent auditor's information rent.

The probability of audit switching. Under an audit retendering regime, the firm switches its auditor only when receiving an external bid lower than the incumbent auditor. Denote by $\left\{\phi_{h}, \phi_{l}\right\}$ the probability of switching to the entrant auditor when the control risk is high and low, respectively. When the control risk is high, the incumbent always bids the maximum audit fee $w_{h}$. As such, the entrant auditor wins the audit engagement when her bid is below $w_{h}$, which leads to 
a total probability of switching,

$$
\phi_{h}=G_{O}\left(w_{h}\right)=1-\lambda .
$$

When the control risk is low, however, both the incumbent and the entrant auditors play mixed strategies $\left\{G_{O}(F), G_{I}^{l}(F)\right\}$ over the bidding range. In this case, the probability that the entrant auditor wins the audit engagement becomes

$$
\phi_{l}=\int_{\bar{w}}^{w_{h}} G_{O}(F) g_{I}^{l} d F=(1-\lambda) / 2
$$

In equilibrium, the entrant auditor is more likely to win the audit engagement when the control risk is high rather than low $\left(\phi_{h}>\phi_{l}\right)$. This result is known as the "winner's curse" in the literature (Milgrom and Webber 1982). Ex ante, without observing the control risk, the client firm expects to switch to the entrant auditor with the probability of

$$
\phi \equiv \lambda \phi_{h}+(1-\lambda) \phi_{l}=\frac{1-\lambda^{2}}{2}
$$

Proposition 2 Under audit retendering, the client firm with high control risk is more likely to switch to the entrant auditor ex post than the firm with low control risk, i.e., $\phi_{h}>\phi_{l}$. The ex-ante overall likelihood of switching decreases when the probability of high control risk increases (a higher $\lambda)$, i.e., $\frac{d \phi}{d \lambda}<0$.

\subsection{The Investors' Problem and Firm Payoff}

We now solve the investors' problem on Date 3. Before providing capital $K$ to the firm, investors observe the following: (1) whether an auditor switch has occurred, and (2) the issued auditor's report. Following the information structure assumption in (1), investors provide capital if and only if a good report is observed. Corollary 2 suggests that under the audit retendering regime, the auditor that wins the engagement contains information about the unobservable control risk. While investors cannot observe the client firm's true control risk and audit quality, they know that the entrant auditor is more likely to win the audit engagement when the control risk is high. That is, 
the auditor switch itself conveys information to investors.

Investors take into account both the auditor's report and the auditor switch when updating their belief about the project state, and request a fraction $\alpha_{a}$ of the project return to break even in providing the capital investment $K$, where $a \in\{O, I\}$ indicates the report issued by an outside auditor or an incumbent auditor. The investors' expected payoff is given by

$$
V\left(\alpha_{a}, K\right)=\alpha_{a} \operatorname{Pr}(G \mid g, a) R-K, \text { for } a \in\{O, I\}
$$

In the competitive market, investors are expected to break even from the investment, $V\left(\alpha_{a}, K\right)=0$. Thus, in equilibrium, investors request a fraction $\alpha_{a}^{*}$,

$$
\alpha_{a}^{*}=\frac{K}{\operatorname{Pr}(G \mid g, a) R}
$$

The investors' fraction decreases with the investors' updated belief about the project's state being good upon observing the auditor's good report, which we call the informativeness of the auditor's report. Under auditor retendering, the investors' updated belief depends on the identity of the auditor who issues the good report, $\operatorname{Pr}(G \mid g, O)$ and $\operatorname{Pr}(G \mid g, I)$. Specifically, investors take into account the probabilities of switching to an outside auditor, $\phi_{h}$ and $\phi_{l}$, for the high- and low-control-risk firm when updating their belief. Therefore, we have

$$
\begin{aligned}
\operatorname{Pr}(G \mid g, O) & =\frac{\phi p}{\phi p+(1-p)\left[\lambda \phi_{h}\left(1-q_{h}\right)+(1-\lambda) \phi_{l}\left(1-q_{l}\right)\right]} \\
\text { and } \operatorname{Pr}(G \mid g, I) & =\frac{(1-\phi) p}{(1-\phi) p+(1-p)\left[\lambda\left(1-\phi_{h}\right)\left(1-q_{h}^{I}\right)+(1-\lambda)\left(1-\phi_{l}\right)\left(1-q_{l}\right)\right]},
\end{aligned}
$$

where $\phi \equiv \lambda \phi_{g}+(1-\lambda) \phi_{b}$ is the overall expected probability of switching. If the entrant auditor wins the audit engagement, investors conjecture that the audit effort level will be $q_{h}$ and $q_{l}$ in the high- and low-risk firms respectively. However, if the incumbent auditor wins the audit engagement, the investors' conjecture of the audit effort level in the high-control-risk firm is $q_{h}^{I}$, which is larger than the effort provided by an entrant auditor $q_{h}$.

The informativeness of the auditor's good report issued by the entrant and incumbent auditors, $\operatorname{Pr}(G \mid g, O)$ and $\operatorname{Pr}(G \mid g, I)$, are different due to two factors: (1) the auditor switch occurs more 
often in the high-control-risk firm, i.e., $\phi_{h}>\phi_{l}$. This suggests that when the entrant (incumbent) auditor issues the good report, investors assign a greater (less) weight to the high-control-risk firm, which is subject to a greater type-II error; and (2) the incumbent auditor's audit quality is higher than the outside auditor in the high-control-risk firm. Combining the effects from these two factors, we have the following proposition.

Proposition 3 Under an audit retendering regime, the entrant auditor's report is less informative about the good project state than the incumbent auditor's, i.e., $\operatorname{Pr}(G \mid g, O)<\operatorname{Pr}(G \mid g, I)$. Investors request a higher fraction of the project return when the audit report is issued by the entrant auditor than when it is issued by the incumbent, $\alpha_{O}^{*}>\alpha_{I}^{*}$.

Notice that even if the incumbent auditor does not have any knowledge advantage over the entrant auditor (i.e., $q_{h}^{I}=q_{h}$ ), the information asymmetry in the bidding alone leads to different informativeness levels of auditors' reports that determine investors' equilibrium fraction of return.

We then calculate the firm's expected payoff under audit retendering. The firm receives its share in the project return only when the project is funded and the good state is realized. Moreover, the auditor's report may be either from the incumbent or the entrant auditor. Taking into account the overall probability of an auditor switch, $\phi$ in (8), the firm's expected payoff under audit retendering is given by

$$
W_{t}\left(\alpha_{a}^{*}, F_{t}^{*}\right)=p R\left[1-\left(\phi \alpha_{O}^{*}+(1-\phi) \alpha_{I}^{*}\right)\right]-F_{t}^{*}
$$

Substituting $\alpha_{a}^{*}$ from (9) and $F_{t}^{*}$ from (7) into the firm's payoff function above, we obtain

$$
\begin{aligned}
W_{t}\left(\alpha_{a}^{*}, F_{t}^{*}\right)= & p(R-K)-(1-p) K\left\{\lambda\left[\phi_{h}\left(1-q_{h}\right)+\left(1-\phi_{h}\right)\left(1-q_{h}^{I}\right)\right]+(1-\lambda)\left(1-q_{l}\right)\right\} \\
& -\bar{w}-\lambda(1-\lambda)\left(w_{h}-w_{l}\right) .
\end{aligned}
$$

The firm's expected payoff is the expected project payoff in the good state, subtracting the investment loss due to the type-II error in the auditor's report and minus the expected audit fee. The investment loss depends on the average audit quality from the auditors, taking into account that the auditor may switch in the audit retendering regime. When the incumbent auditor remains 
engaged in auditing the high-control-risk firm, which occurs with a probability of $1-\phi_{h}$, the audit quality is $q_{h}^{I}$, higher than that of the entrant auditor. The audit switch in the low-control-risk firm does not affect the investment loss, however, because for the low-risk firm, the incumbent and entrant auditors' cost are the same, which leads to the same level of audit quality.

\subsection{Empirical implications}

Our analysis under an audit retendering regime offers testable empirical implications for clientinitiated auditor changes and explains some empirical findings in the literature. Audit tenders are not uncommon in practice. Client firms can always voluntarily tender their audit services, which may result in an auditor switch. Beattie and Fearnley (1998) found that about 55\% of auditor changes in U.K. companies were caused by an audit tender. However, firms typically do not disclose in detail the tender process that leads to such switch, making it hard to identify an auditor switch driven by a optimal tender process or by an opportunistic incentive, such as opinion shopping. Even if a client firm might have gone through a tender process, the incumbent auditor still wins the bid and remains engaged. Thus it is empirically hard to test the outcome of the auditor tender directly, as predicted by our model. With the caveat of the unobservability of the tender process, we next discuss how our theoretical results can shed light on the determinants and consequences of an auditor switch on average.

Prior empirical studies have documented the audit fee discounts when firms switch auditors (Simon and Francis, 1988; Deis and Girous, 1996), which is consistent with our model's prediction. As shown in our model, this fee discount is not driven by the entrant auditor's low-balling incentive, but is primarily due to the information disadvantage of the entrant auditor. Deis and Girous (1996) also found that new auditors spend longer audit hours after the switch, consistent with our model, in which high-control-risk firms are more likely to switch, leading to higher costs for entrant auditors. Our result in Corollary 1 predicts that for these switchers, the fee discount is larger when the firm's control risk is higher or if the audit procedure is more complex or costly, which can be tested cross-sectionally.

We also provide theoretical explanations for empirical findings on the consequences of auditor 
switches. Our result that an auditor switch itself conveys information to the market regarding the underlying client risk is consistent with the negative market reaction to auditor switching in Weiss and Kalbers (2008). Furthermore, Kim and Park (2006) found that firms switching auditors underprice to a greater degree in their seasoned equity offerings. This result is consistent with Corollary 3 , in that that the entrant auditor's report is less informative to investors, thereby leading to more underpricing. Our model also offers a cautionary note in drawing policy implications on mandatory auditor rotation based on the empirical findings from auditor switches under the current regime, because the voluntary auditor switch reveals additional firm information to the market; while auditor switches under mandatory auditor rotation do not have such information content.

\section{Mandatory Auditor Rotation}

In this section, we consider the mandatory auditor rotation regime in which the client firm is required to hire a new auditor from the audit market at the beginning of the period. Only an external auditor can engage in the audit service under mandatory auditor rotation, and there is no competitive bidding between the external and incumbent auditors.

The timeline of events is as follows. The firm hires an auditor and pays an audit fee of $F_{m}$, which allows the auditor to break even in expectation. After engagement, the auditor privately observes the control risk and exerts audit effort $q$ to issue an audit report. If the audit report is $b$, the project is not funded and the game ends. If the audit report is $g$, the project is funded by selling $\alpha_{m}$ share of the firm to investors. If the project is funded, the cash flow is realized later. In case of success, investors receive an $\alpha_{m}$ portion of the cash flow $R$. In case of failure, investors receive zero.

The auditor's problem. After the audit engagement, the auditor perfectly observes the control risk of the client firm and chooses effort $q$ to maximize the expected payoff, $U_{r}\left(q, F_{m}\right)$, which is defined as

$$
U_{r}\left(q, F_{m}\right)=F_{m}-w\left(q, c_{r}\right),
$$


where $F_{m}$ is the audit fee, and $w\left(q, c_{r}\right)$ is the expected total audit cost for the client firm with control risk $r, r \in\{l, h\}$.

The total audit cost is the cost of audit effort plus the expected litigation cost. The cost of effort depends on the control risk. Because the engaging auditor is always an external auditor who does not have private information about the control risk, the marginal cost of audit is always $c_{r}$. A litigation cost is only incurred when a type-II error exists. Therefore, the expected total audit cost is

$$
w\left(q, c_{r}\right)=(1-q)(1-p) L+c_{r} \psi(q) .
$$

Thus, the auditor chooses the optimal effort by solving the following problem:

$$
q_{r} \in \underset{q}{\arg \max _{q}} U_{r}\left(q, F_{m}\right)=F_{m}-w\left(q, c_{r}\right)
$$

Substituting $\psi(q)=q^{2} / 2$ and $w\left(q, c_{r}\right)$ into (15), and solving the first-order condition for $q$, we obtain

$$
q_{r}=\frac{(1-p) L}{c_{r}}
$$

To ensure that the audit effort $q_{r}$ in equilibrium is less than one $\left(q_{r}<1\right)$, we assume that the legal cost $L$ is not too large; that is, $L<c_{r} /(1-p)$. Clearly, audit fee $F_{m}$ has no direct impact on the audit effort $q_{r}$, because $F_{m}$ is determined before the engagement. The auditor essentially chooses the effort level to minimize the expected total cost, taking the audit fee as exogenous.

Corollary 1 Under a mandatory rotation regime, the auditor exerts higher effort for the low-risk firm than the high-risk firm, i.e., $q_{h}<q_{l}$. Holding the control risk constant, the audit effort $q_{r}$ increases in the legal cost $L$.

The audit fee. In a competitive audit market, the auditor expects to break even from the audit engagement. Given optimal effort levels $q_{h}$ and $q_{l}$ in (16), the auditor's ex-ante expected 
payoff prior to observing the control risk is

$$
E\left[U\left(F_{m}, q_{h}, q_{l}\right)\right]=F_{m}-\left[\lambda w_{h}+(1-\lambda) w_{l}\right]
$$

where $w_{h}=\left(1-q_{h}\right)(1-p) L+c_{h} \psi\left(q_{h}\right), w_{l}=\left(1-q_{l}\right)(1-p) L+c_{l} \psi\left(q_{l}\right)$, and $q_{r}$ is given in (16). Thus, the firm offers the audit fee $F_{m}^{*}$ that satisfies the auditor's break-even condition. Setting $E\left[U\left(F_{m}, q_{h}, q_{l}\right)\right]=0$, we obtain

$$
F_{m}^{*}=\lambda w_{h}+(1-\lambda) w_{l} \equiv \bar{w}
$$

As shown above, the audit fee covers the ex-ante expected total cost of the audit engagement, which we denote as $\bar{w}$.

Corollary 2 The audit fee $F_{m}^{*}$ increases with the legal cost $L\left(\partial F_{m}^{*} / \partial L>0\right)$, the probability of high control risk $\lambda\left(\partial F_{m}^{*} / \partial \lambda>0\right)$, and the marginal cost of audit effort $c_{r}\left(\partial F_{m}^{*} / \partial c_{r}>0\right)$.

The investors' problem. Investors cannot directly observe the true project state $\{G, B\}$, and rely on the audit report to update their belief. Following the assumption in (1), a bad audit report perfectly reveals the bad state $-\operatorname{Pr}(B \mid b)=1$-in which case the investors always receive zero payoff. Hence investors provide capital to the firm if and only if the audit report is $g$. Given a good audit report $g$ and the equilibrium audit effort $q_{h}$ and $q_{l}$, the investors' posterior belief in the project's good state $\operatorname{Pr}(G \mid g)$ is

$$
\operatorname{Pr}(G \mid g)=\frac{p}{p+(1-p)\left[\lambda\left(1-q_{h}\right)+(1-\lambda)\left(1-q_{l}\right)\right]} .
$$

Thus, investors require a fraction $\alpha_{m}$ of the project return for providing capital investment $K$, which gives the expected payoff as

$$
V\left(\alpha_{m}, K\right)=\alpha_{m} \operatorname{Pr}(G \mid g) R-K \text {. }
$$

In a competitive market, investors earn normalized zero-expected returns from the investment. 
Thus, by setting the investor's payoff $V\left(\alpha_{m}, K\right)$ to zero, we obtain the equilibrium fraction $\alpha_{m}^{*}$,

$$
\alpha_{m}^{*}=\frac{K}{\operatorname{Pr}(G \mid g) R} .
$$

Intuitively, the investors' share of the project return decreases with the posterior belief $\operatorname{Pr}(G \mid g)$, which indicates the informativeness of the audit report. The higher the audit effort, the more informative the auditor's report. Thus, investors request a lower fraction of the project if the equilibrium audit effort is higher. Following Remark 1, we obtain the following results regarding the investors' equilibrium share.

Corollary 3 Investors request a higher fraction $\alpha_{m}^{*}$ when the legal cost $L$ is lower $\left(\partial \alpha_{m}^{*} / \partial L<0\right)$, the probability of high control risk is higher $\left(\partial \alpha_{m}^{*} / \partial \lambda>0\right)$, or when the marginal cost of audit effort is higher $\left(\partial \alpha_{m}^{*} / \partial c_{r}>0\right)$.

The firm's problem. The firm receives the remaining $1-\alpha_{m}$ fraction of the project's cash flows when the project is funded and the good state is realized. The firm's overall expected payoff, denoted as $W\left(\alpha_{m}, F_{m}\right)$, is thus characterized by

$$
W\left(\alpha_{m}, F_{m}\right)=p\left(1-\alpha_{m}\right) R-F_{m} .
$$

The firm's expected payoff is the expected return on the project minus the audit fee. If investors request a fraction of $\alpha_{m}$ in the project's cash flows upon a good signal, the firm's expected return on the project then becomes $p\left(1-\alpha_{m}\right) R$, because the good state always generates a good signal $(P(g \mid G)=1)$. As previously discussed, given the competitive audit market and capital market, both the auditor and investors earn zero expected return in equilibrium, which determines $\alpha_{m}^{*}$ and $F_{m}^{*}$ as stated in (20) and (18) respectively. It is clear that the firm's expected payoff decreases with $\alpha_{m}^{*}$ and $F_{m}^{*}$. Corollaries 2 and 3 imply that when the probability of high control risk $\lambda$ increases, or when the marginal cost of audit effort $c_{r}$ increases, the expected firm payoff always decreases because of both a higher audit fee and a larger investor share. However, when the auditor's litigation cost increases, it leads to a higher equilibrium audit fee (Corollary 2), but a lower investors' share (Corollary 3). This is because a higher litigation cost induces a higher audit effort (see Eq.16), 
which reduces the type-II error so that investors request a lower share in return. For the auditor, however, the total expected audit cost is actually higher in equilibrium, because the litigation cost also has a direct effect on the audit cost.

We substitute $\alpha_{m}^{*}$ and $F_{m}^{*}$ into the firm's payoff function, and obtain that

$$
W\left(\alpha_{m}^{*}, F_{m}^{*}\right)=p(R-K)-(1-p)\left[\lambda\left(1-q_{h}\right)+(1-\lambda)\left(1-q_{l}\right)\right] K-\bar{w}
$$

where $\bar{w}$ follows (18). The firm's expected payoff has three components: the first term represents the project return in the good state, the second term is the investment loss due to an audit failure (i.e., a type-II error) and the third term is the expected total audit costs. In equilibrium, the firm bears the investment loss and the total audit cost, both of which depend on the equilibrium audit effort as stated in (16).

\section{Comparison between Audit Retendering and Auditor Rotation}

\subsection{Comparison of the Expected Audit Fee}

To facilitate comparisons between two regimes, we juxtapose the expected audit fees in the following table. Under the auditor rotation regime, the audit fee is always equal to the expected audit cost in order for the auditor to break even, $E\left[F_{m}^{*}\right]=\bar{w}$ from (18). Under audit retendering, the expected audit fee is given by $(7), E\left[F_{t}^{*}\right]=\bar{w}+\lambda(1-\lambda)\left(w_{h}-w_{l}\right)$.

It is easy to see that the client firm's expected audit fee under audit retendering is always higher than that under mandatory auditor rotation. To see this, recall that under the audit retendering regime, both the entrant auditor and the incumbent auditor (in the low-risk firm) adopt a randomized bidding strategy in the range $\left[\bar{w}, w_{h}\right]$, where the lower bound of the bidding range is exactly the same as the expected audit fee under the mandatory rotation regime. When the control risk is high, the incumbent auditor always bids $w_{h}$, also strictly higher than $\bar{w}$. Thus, it is intuitive that the expected audit fee from the bidding outcome always exceeds the lower bound $\bar{w}$, which is the expected audit fee under the mandatory rotation regime. 


\begin{tabular}{|l|l|l|}
\hline Regime & Audit fees $F$ & Comparison \\
\hline & & \\
\hline Rotation: & $E\left[F_{m}^{*}\right]=\bar{w}=\lambda w_{h}+(1-\lambda) w_{l}$ & Benchmark \\
\hline Retendering: & $E\left[F_{t}^{*}\right]=\bar{w}+\lambda(1-\lambda)\left(w_{h}-w_{l}\right)$ & Higher \\
\hline
\end{tabular}

Proposition 4 The expected audit fee under audit retendering is always higher than that under mandatory auditor rotation.

The difference between audit fees in the two regimes is

$$
\Delta F \equiv E\left[F_{t}^{*}\right]-E\left[F_{m}^{*}\right]=\lambda(1-\lambda)\left(w_{h}-w_{l}\right)
$$

The firm's total expected audit fee in the audit retendering regime consists of two parts: the breakeven audit fee $\bar{w}$, which is the expected audit cost from the entrant auditor's perspective, and the incumbent auditor's expected profit in the low-control-risk firm, $\lambda(1-\lambda)\left(w_{h}-w_{l}\right)$. As discussed in the bidding game of Section 5.1, the incumbent auditor earns a strictly positive constant profit of $U_{I}^{l}(F)=\lambda\left(w_{h}-w_{l}\right)$ when the control risk is low. Therefore, overall, the incumbent auditor earns an expected profit of $(1-\lambda) U_{I}^{l}(F)=\lambda(1-\lambda)\left(w_{h}-w_{l}\right)$ in the low-control-risk firm, which is exactly the fee difference in (22). Even though the incumbent auditor also earns a strictly positive profit in the high-risk firm, this does not add an incremental fee from the firm's perspective when compared to the mandatory rotation regime. The incumbent's profit in the high-control-risk firm is due to its knowledge advantage in auditing the high-control-risk firm. However, this part of the cost efficiency does not lower the audit fee, since the incumbent auditor always bids as if he incurs the same cost as the entrant. As a result, the audit fee difference under these two regimes is driven exclusively by the incumbent auditor's information rent in the low-control-risk firm. The fee difference is purely driven by the information advantage of the incumbent auditor; that is, the difference still exists even if the incumbent auditor does not gain any knowledge advantage over the entrant auditor from his prior engagement with the firm. 


\subsection{Comparison of the Audit Report Informativeness}

We next analyze the informativeness of the audit report under the two regimes. Under the mandatory rotation regime, the auditor report informativeness is $\operatorname{Pr}(G \mid g)$ from (19), while under the audit retendering regime, the audit report informativeness is either $\operatorname{Pr}(G \mid g, O)$ from (10) or $\operatorname{Pr}(G \mid g, I)$ and (11), depending on the auditor who issues the report. In Proposition 3, we have already shown that under the audit retendering regime, the audit report issued by the incumbent auditor is more informative than that of the entrant auditor. We now compare the informativeness of each type of auditor's report under audit retendering with that of the report under mandatory rotation.

We first compare the informativeness of the entrant auditor's report $\operatorname{Pr}(G \mid g, O)$ under audit retendering with the report under mandatory rotation $\operatorname{Pr}(G \mid g)$. In both cases, the auditor's efforts for high- and low-control-risk firms are both $q_{h}$ and $q_{l}$ respectively, because both reports are issued by the entrant auditor who has no prior engagement with the firm. However, the informativeness of these two reports remains different due to the information conveyed by the audit switch under the audit retendering regime. To see this, rewrite $\operatorname{Pr}(G \mid g, O)$ in (10) as

$$
\operatorname{Pr}(G \mid g, O)=\frac{p}{p+(1-p)\left[\lambda \frac{\phi_{h}}{\phi}\left(1-q_{h}\right)+(1-\lambda) \frac{\phi_{l}}{\phi}\left(1-q_{l}\right)\right]},
$$

where $\phi_{h}$ and $\phi_{l}$ are the probabilities of an audit switch in the high- and low-control-risk firms respectively, and $\phi=\lambda \phi_{h}+(1-\lambda) \phi_{l}$ is the overall expected probability of the switch. Under the audit retendering regime, when investors observe the audit report by the entrant auditor, they update their prior belief about the auditor's type-II error with the weights on the high- and low-risk

firm as $\frac{\phi_{h}}{\phi}$ and $\frac{\phi_{l}}{\phi}$, respectively. Because an audit switch for the high-risk firm is more likely than the low-risk firm, $\phi_{h}>\phi>\phi_{l}$, investors assign greater weight to the high-risk firm, which has a lower audit quality than the low-risk firm. Therefore, the audit report from the entrant auditor under mandatory rotation is less informative than the one under audit retendering, $\operatorname{Pr}(G \mid g, O)<\operatorname{Pr}(G \mid g)$.

We next compare the informativeness of the incumbent auditor's report $\operatorname{Pr}(G \mid g, I)$ with the report under mandatory rotation $\operatorname{Pr}(G \mid g)$. The difference in the informativeness of these two reports is driven not only by the additional information conveyed through audit retention, but also 
by the incumbent auditor's ability to conduct a higher audit quality in the high-risk firm. When the audit switch does not occur under audit retendering, the investors believe that the firm's control risk is more likely to be low; thus they update their prior belief by assigning greater weight to the low-risk firm, which has a higher audit quality than the high-risk firm. As such, we can rewrite $\operatorname{Pr}(G \mid g, I)$ in $(11)$ as

$$
\operatorname{Pr}(G \mid g, I)=\frac{p}{p+(1-p)\left[\lambda \frac{1-\phi_{h}}{1-\phi}\left(1-q_{h}^{I}\right)+(1-\lambda) \frac{1-\phi_{l}}{1-\phi}\left(1-q_{l}\right)\right]},
$$

and the weights on the high- and low-risk firms are $\left(1-\phi_{h}\right) /(1-\phi)<1$ and $\left(1-\phi_{l}\right) /(1-\phi)>1$ respectively. Hence, the audit report by the incumbent auditor is more informative. In addition, because the incumbent auditor has a lower marginal cost in conducting the audit in the high-risk firm, the audit quality is higher than that of an entrant auditor with no prior engagement, $q_{h}^{I}>q_{h}$. This also further increases the informativeness of the audit report from the incumbent under the audit retendering regime. Thus, combining these two factors, we have $\operatorname{Pr}(G \mid g, I)>\operatorname{Pr}(G \mid g)$.

Notice that the above mentioned comparison results, $\operatorname{Pr}(G \mid g, O)<\operatorname{Pr}(G \mid g)<\operatorname{Pr}(G \mid g, I)$, still hold even if the incumbent auditor does not have any knowledge advantage over the entrant auditor. That is, the audit switch through audit tendering with asymmetric information provides additional information to the investors.

On average, the expected informativeness of an auditor's report (before the switch) under audit retendering, denoted by $E[\operatorname{Pr}(G \mid g)]$, is always higher than that under mandatory rotation, i.e., $E[\operatorname{Pr}(G \mid g)]>\operatorname{Pr}(G \mid g)$. This difference, however, is purely driven by the incumbent auditor's knowledge advantage, which allows him to deliver a higher audit quality after winning the audit engagement in the high-risk firm. By contrast, under mandatory rotation, such a knowledge advantage is not retained and the audit quality is always the same across different periods.

\begin{tabular}{|l|l|l|}
\hline Regime & The informativeness of the audit report & Comparison \\
\hline & & \\
\hline Rotation: & $\operatorname{Pr}(G \mid g)$ & Benchmark \\
\hline Retendering: Entrant & $\operatorname{Pr}(G \mid g, O)$ & Lower \\
\hline Retendering: Incumbent & $\operatorname{Pr}(G \mid g, I)$ & Higher \\
\hline Retendering: Ex-ante & $E[\operatorname{Pr}(G \mid g)]$ & Higher \\
\hline
\end{tabular}

As the audit report becomes more informative, investors request a lower fraction of the project 
return. It thus follows directly that under mandatory auditor rotation, investors request a higher (lower) fraction than when the audit report is issued by the incumbent (entrant) auditor under the audit retendering regime $\left(\alpha_{O}^{*}>\alpha_{m}^{*}>\alpha_{I}^{*}\right)$. We summarize the results in the following table.

\begin{tabular}{|l|l|l|}
\hline Regime & Required Fraction $\alpha$ & Comparison \\
\hline & & \\
\hline Rotation: & $\alpha^{*}=\frac{K}{\operatorname{Pr}(G \mid g) R}$ & Benchmark \\
\hline Retendering: Entrant & $\alpha_{O}^{*}=\frac{K}{\operatorname{Pr}(G \mid g, O) R}$ & Higher \\
\hline Retendering: Incumbent & $\alpha_{I}^{*}=\frac{K}{\operatorname{Pr}(G \mid g, I) R}$ & Lower \\
\hline
\end{tabular}

Proposition 5 In the presence of information asymmetry,

- the informativeness of the audit report under mandatory auditor rotation is lower (higher) than the incumbent (entrant) auditor's report under audit retendering (i.e., $\operatorname{Pr}(G \mid g, O)<$ $\operatorname{Pr}(G \mid g)<\operatorname{Pr}(G \mid g, I))$

- the expected informativeness of the audit report under audit retendering is always higher than under mandatory rotation $(E[\operatorname{Pr}(G \mid g)]>\operatorname{Pr}(G \mid g))$;

- the investors' requested fraction under mandatory auditor rotation is higher (lower) than when the audit report is issued by the incumbent (entrant) auditor under audit retendering $\left(\alpha_{O}^{*}>\alpha_{m}^{*}>\alpha_{I}^{*}\right)$.

\subsection{Comparison of the Firm's Expected Payoff}

We compare the client firm's expected payoff under two regimes in this section. The firm's expected payoff depends on the investment loss due to the auditor's type-II error and the audit fee paid. Specifically, under the mandatory rotation regime, the client firm's expected payoff is $W_{m}^{*}$ as stated in (21); under the audit retendering regime, the firm's expected payoff is $W_{t}^{*}$ stated in(12). Denote by $\Delta W$ the difference of the client firm's expected payoff between two regimes, and we have

$$
\begin{aligned}
\Delta W & \equiv W_{t}\left(\alpha_{I}^{*}, \alpha_{O}^{*} F_{t}^{*}\right)-W_{m}\left(\alpha_{m}^{*}, F_{m}^{*}\right) \\
& =(1-p)\left\{\lambda\left[\phi_{h}\left(1-q_{h}\right)+\left(1-\phi_{h}\right)\left(1-q_{h}^{I}\right)\right]-\lambda\left(1-q_{h}\right)\right\} K-\left(F_{t}^{*}-F_{m}^{*}\right) \\
& =\lambda(1-p)\left(1-\phi_{h}\right)\left(q_{h}^{I}-q_{h}\right) K-\lambda(1-\lambda)\left(w_{h}-w_{l}\right) .
\end{aligned}
$$


In (25), the first term represents the difference in the investment loss due to the auditor's type-II error, and the second term represents the difference in audit fee, which is the incumbent auditor's information rent under the audit retendering regime. On the one hand, the expected audit fee is higher under the audit retendering regime than under mandatory auditor rotation, because the incumbent auditor earns information rent under audit retendering. On the other hand, the expected investment loss due to a type-II error is smaller under audit retendering than under mandatory rotation, because the incumbent auditor accumulates firm-specific knowledge or expertise that reduces the cost of auditing, which in turn improves the audit quality and reduces the type-II error. In equilibrium, the comparison of the two regimes depends the economic trade-off between information rent and audit efficiency.

Substituting the equilibrium $\left\{w_{h}, w_{l}, \phi_{h}, q_{h}^{I}, q_{h}\right\}$ into (25), we obtain

$$
\Delta W=\lambda L(1-p)^{2}\left[\frac{\lambda K\left(c_{h}-c_{h}^{I}\right)}{c_{h} c_{h}^{I}}-(1-\lambda) \frac{L\left(c_{h}-c_{l}\right)}{2 c_{h} c_{l}}\right] .
$$

We can thus derive the following comparative statics results about the firm's expected payoff. First, when the client firm's control risk is more homogeneous (i.e., $c_{h}$ is closer to $c_{l}$ ), the incumbent's private information is less valuable, resulting in a lower information rent. Second, when the incumbent auditor's knowledge advantage is larger (i.e., a smaller $c_{h}^{I}$ ), the client firm is better off with audit retendering, because the reduction in investment loss is expected to be larger. Third, when the required investment $K$ is larger, audit retendering results in a higher firm payoff, because the investment loss due to the entrant auditor's low audit quality under mandatory rotation is more severe. When the control risk is more likely to be high (a high $\lambda$ ), the incumbent's information rent is smaller, suggesting that the client firm is more likely to benefit from audit retendering.

Proposition 6 The client firm's payoff under audit retendering is larger than under mandatory auditor rotation when

- the client firm's control risk is more homogeneous (i.e., $c_{h}-c_{l}$ is small); or

- the incumbent auditor's knowledge advantage is higher (i.e., a smaller $c_{h}^{I}$ ); or 
- the required investment $K$ is larger; or

- the control risk is more likely to be high (a higher $\lambda$ ).

Lastly, the effect of the legal cost $L$ on the firm's expected payoff is unclear. On the audit efficiency side, higher legal costs lead to a larger difference in audit quality due to the incumbent auditor's knowledge advantage, which reduces the investment loss even more. On the information rent side, higher legal costs also directly increase the audit fee, which increases the incumbent's information rent relative to the fee under mandatory rotation. We identify a threshold for the required investment $K^{*}$, such that for $K>K^{*}$, the client firm is more likely to benefit from audit retendering when the legal cost is higher $(\partial \Delta W / \partial L>0)$.

Corollary 4 There exists a threshold $K^{*}$ such that for $K>K^{*}$, the client firm's payoff under audit retendering is larger than under mandatory auditor rotation, when the legal cost $L$ is higher $(\partial \Delta W / \partial L>0)$.

\subsection{Regulatory Implications}

We have compared the firm's expected payoff under two audit regulations: auditor rotation and audit retendering. As Proposition 6 shows, client firms are not necessarily better off with either regulation. We next analyze the economic trade-offs between the two regulations from a regulator's perspective. To facilitate the analysis, we assume that the regulator's objective is to maximize the social welfare, which is a weight average of the players' expected payoffs, including the client firm, the investor, the incumbent auditor, and the entrant auditor. Denote by $W_{R}$ the regulator's payoff with a weight $\gamma \in[0,1]$ on the firm's payoff. Under mandatory auditor rotation, both the auditor and investors break even in equilibrium. Thus, the regulator's payoff equals the proportion $\gamma$ of the firm's expected payoff $\left(W_{R}^{m}=\gamma W_{m}\left(\alpha_{m}^{*}, F_{m}^{*}\right)\right)$. By contrast, under audit retendering, while both the entrant auditor and investors break even (i.e., $E\left[U_{O}(F)\right]=0$ ), the incumbent auditor expects to earn a positive payoff due to information advantage. The regulator's expected payoff is given by $W_{R}^{r}=\gamma W_{r}\left(\alpha_{r}^{*}, F_{r}^{*}\right)+(1-\gamma) U_{I}(F)$. The difference of the regulator's payoff under the two 
regulations is

$$
\begin{aligned}
\Delta W_{R} & =W_{R}^{r}-W_{R}^{m}=\gamma W_{r}\left(\alpha_{r}^{*}, F_{r}^{*}\right)+(1-\gamma) U_{I}(F)-\gamma W_{m}\left(\alpha_{m}^{*}, F_{m}^{*}\right) \\
& =\gamma\left[W_{r}\left(\alpha_{r}^{*}, F_{r}^{*}\right)-W_{m}\left(\alpha_{m}^{*}, F_{m}^{*}\right)\right]+(1-\gamma) U_{I}(F) \\
& =\gamma \Delta W+(1-\gamma) U_{I}(F) \\
& =\gamma \lambda(1-p)\left(1-\phi_{h}\right)\left(q_{h}^{I}-q_{h}\right) I+(1-2 \gamma) \lambda(1-\lambda)\left(w_{h}-w_{l}\right)
\end{aligned}
$$

where the first term relates to the client firm's investment loss, and the second term relates to the incumbent auditor's information rent. When the regulator is equally concerned about the client firm's and the auditor's payoff (i.e., $\gamma=1 / 2$ ), the regulator is strictly better off with audit retendering $\left(\Delta W_{R}>0\right)$. However, if the regulator places slightly greater weight on the client firm's payoff $(\gamma>1 / 2)$, audit retendering does not always lead to a higher payoff to the regulator, and the results of Proposition 6 hold from the regulator's perspective as well. That is, given $\gamma>1 / 2$, the regulator would prefer auditor retendering when the auditor's information rent is small or when the incumbent auditor's higher audit quality is more important to reduce the investment loss.

\section{Discussions}

\subsection{Auditor Independence}

We focus on the economic trade-off between information rent and audit efficiency under two regimes, and do not explicitly incorporate auditor independence issues. Conventional wisdom holds that auditor independence is more likely to be maintained under a mandatory auditor rotation regime, because a long-term engagement might lead auditors to become more aligned with the client and lose their independence. Thus, it is essential for us to provide some discussion regarding the implications of auditor independence in our model. We argue that in our model, auditor independence is not necessarily more likely to be compromised under audit retendering than under mandatory auditor rotation. We support this argument from two perspectives through informal discussions of incorporating auditor independence in our model.

In our model, the incumbent auditor earns positive information rent (value of incumbency). 
One may think that the threat of losing future information rent could make the incumbent auditor more likely to compromise an auditor report. However, information rent here is very different from the quasi-rent driven by switching costs, as discussed in DeAngelo (1981). First, unlike switching costs, information rent is inevitable, as long as the incumbent auditor has an information advantage and is allowed to participate in audit tenders. Second, the client firm cannot verify whether the auditor earns information rent or not ex-post, because the incumbent auditor's private information regarding the client-specific risk is not verifiable and never revealed. The firm, without observing the control risk, accepts the lowest bid from the auditors and switches only when an outside auditor bids a lower price than the incumbent. The client firm thus cannot obtain a favorable auditor report by credibly threatening the termination of the incumbent auditor. In other words, the information rent earned by the incumbent auditor does not necessarily decrease auditor independence.

Alternatively, we can address the independence issue from an ex-post perspective. We argue that it is more costly for the client firm to induce the auditor to compromise her independence under audit retendering than under mandatory auditor rotation. In our model, when the audit evidence is bad, the auditor knows that additional legal costs will result later if she misreports it as good. To compromise an audit report, the client firm needs to compensate the additional audit liability borne by the auditor, as in Deng et al (2014). However, the legal cost for compromising the audit report is different between the incumbent and the entrant auditors. Because of his knowledge advantage, the incumbent auditor delivers a higher quality audit service and is more likely to detect a bad state when the client firm's control risk is high. This suggests that the incumbent auditor's expected legal costs are higher if he compromises his independence. In other words, holding the benefit of compromising the audit report constant, the auditor independence is less likely to be an issue under audit retendering.

Supporting our view, most empirical studies do not find evidence that longer auditor tenure always impairs auditor independence. For example, Bamber and Iyer showed that more experienced auditors are less likely to acquiesce to the client's position and that audit firm tenure is associated with a decreased likelihood of auditor concessions. Wang and Tuttle (2009) suggested that under 
mandatory firm rotation, negotiation results are closer to the auditor's preference than that of the client. In the case of Spain, Ruiz-Barbadillo, Gomez-Aguilar, and Carrera (2009) found no empirical evidence that mandatory audit firm rotation is associated with a higher likelihood of issuing going concern opinions. Moreover, the extant literature also largely suggests that financial statement users do not perceive long auditor tenure as a threat to the impairment of auditor independence. Based on a survey of bankers and financial analysts, Shockley (1981) concluded that auditor tenure exceeding five years is not perceived as reducing auditor independence. Ghosh and Moon (2005) found that longer tenure is associated with better earnings quality as perceived by equity market investors. Chi et al. (2009) did not find any impact of partner rotation on actual audit quality (proxied by abnormal accruals) or perceived audit quality (proxied by the ERC) in Taiwan. Theoretically, a recent paper by Dordzhieva (2018) also challenged this view, showing that mandatory rotation could actually impair auditor independence.

\subsection{Audit Tendering Process}

We assume that under audit retendering, the client firm follows a simple rule by selecting the auditor who bids the lowest audit fee. A study by U.K. Competition Commission shows a relative effect of 13 percent fee reduction in the first year after the tender process or switching compared with firms that had not tendered or switched. This fee-based auction is reasonable for the following reasons. In our model, both auditors have same audit technology, except that the incumbent has firm-specific knowledge advantage. We assume implicitly that when soliciting bids from auditors, a firm carefully controls other important factors, such as audit firm size and technology. For example, a firm's audit committee or search committee for audit tender may impose certain criteria when searching and soliciting bids from potential auditors, so that the winning auditor is qualified to deliver the expected audit service. In addition, audit is an experience good where it is only possible to determine its quality in retrospect. Therefore, it is difficult for the client firm to tell in advance how a new auditor will be to work with and its service levels. ${ }^{24}$ Because the audit quality is not

\footnotetext{
${ }^{24}$ See "Statutory audit services for large companies market investigation" issued by U.K. Competition Commission, paragraphs 5.57 and 9.217 .
} 
contractible, it is difficult for the firm to design an auction mechanism that selects the winner based on audit quality. ${ }^{25}$ Hence, as long as the bidding participants meet these basic qualifications, a fee-based auction is a reasonable assumption.

We can quantitatively identify conditions under which the price-based auction is guaranteed as optimal for the firm. In our model, the incumbent auditor and entrant auditor provide exactly the same quality of audit service in the low-control-risk firm. Thus, for low-risk firms, selecting the winner based on a lower fee is always an optimal rule. For high-risk firms, however, when the entrant auditor offers a lower fee than the incumbent (recall the incumbent always offers $w_{h}$ in the high-risk firm), the firm knows that switching to an outside auditor also implies a lower audit quality than using the incumbent. To justify the switch decision, the firm compares the potential benefit of a lower fee with the higher potential audit liability resulting from a type-II error by hiring the entrant auditor. Specifically, when the control risk is high, the expected audit fee difference between the incumbent and entrant auditors is

$$
E\left[F_{I}^{h} \mid r=h\right]-E\left[F_{O} \mid r=h\right]=w_{h}-\int_{\bar{w}}^{w_{h}} F g_{O}(F) d F
$$

The client firm's investment loss due to the difference in audit quality is $\lambda(1-p)\left(q_{h}^{I}-q_{h}\right) K$. Thus, the client firm benefits from hiring an entrant auditor as long as

$$
w_{h}-\int_{\bar{w}}^{w_{h}} F g_{O}(F) d F \geq(1-p)\left(q_{h}^{I}-q_{h}\right) K
$$

It follows that when the audit liability is sufficiently large (relative to the investment level), the audit fee has a larger impact on the firm's expected payoff and the above mentioned condition always holds. Given this condition, a tender process based on audit fee is optimal for the firm.

Intuitively, when the firm risk is high, the incumbent auditor always bids the highest audit fee, $w_{h}$, which is greater than his own expected audit cost $w_{h}^{I}$, while the entrant auditor suffers a loss

\footnotetext{
${ }^{25}$ Note that audit quality is typically regarded as soft information, and it is not contractible. Researchers have identified various factors that potentially affect audit quality and have applied different empirical proxies for audit quality, see DeFond and Zhang (2014). The U.K. Financial Reporting Council does not mandate how a new auditor should be selected. Audit committees may assign different weights to audit fees and other factors affecting audit quality, but the disclosure of such weights is not required.
} 
in the high-risk firm. This fee premium by the incumbent auditor, if too large, makes it optimal for the firm to choose the entrant auditor over the incumbent despite the lower audit quality.

\subsection{Other Issues}

Low-balling. We consider the bidding competition between an informed incumbent and an uninformed entrant. Our goal is to highlight the economic trade-offs under audit retendering given the incumbent's private information and knowledge advantage. From the firm's perspective, audit retendering is more favorable when the incumbent's information rent is smaller. Conceptually, we can extend the analysis to a two-period model. In the first period, two symmetrically uninformed auditors bid for the audit service in a client firm, and the winner becomes the incumbent auditor in the tendering for the client firm's second period. In the first period, because the uninformed auditors know that they will earn information rent in the second period, they discount the audit fee in the first period in order to compete with each other. This is known as low-balling (DeAngelo 1981; Chan 1999; Lee and Gu 1998). If the first-period audit market is perfectly competitive, the second-period information rent may be fully extracted away. In this case, from the client firm's perspective, the negative effect of the information rent would be mitigated. This suggests that given the possibility of low-balling, audit retendering could be more beneficial. The low-balling that arises endogenously in this setting, will not necessarily lead to compromise in audit independence, as previously argued.

Information Acquisition. We assume that the incumbent auditor can perfectly observe the control risk from the prior audit engagements with the client firm. An entrant auditor cannot observe the actual control risk and knows only the distribution. One extension is to assume that in the first period, the engaged auditor needs to incur an information acquisition cost (or some firm-specific investment) in order to assess the client firm's control risk and gain both information and knowledge advantage in auditing the high-risk firm. In this case, the auditor faces a trade-off between the cost of information acquisition and the potential benefit of information rent from the future audit engagement. It is intuitive that under mandatory auditor rotation, an incumbent auditor has no incentive to acquire information or invest in firm-specific technology, because he 
expects to receive no information rent to cover the information acquisition cost. However, under auditor retendering, an auditor has an incentive to make a firm-specific investment, since he may earn information rent in later periods. This suggests that if the cost of information acquisition or firm-specific knowledge investment is high or the client firm's control risk is very valuable, audit retendering is more beneficial than mandatory rotation.

Partially Informed Entrant Auditor. In our model, the entrant auditor only observes the prior distribution regarding the client firm's control risk, and competes with a perfectly informed incumbent auditor. We can easily extend our model to allow the entrant to be partially informed with some noisy signals about the firm's control risk. For example, the entrant auditor may be able to assess the firm's control risk by analyzing the client firm's financial statements or through her prior engagement with another firm in the same industry. The internal control weakness disclosure after Sarbanes-Oxley may also be another source of noisy public information for the entrant. In such a case, the bidding game is a bit more complicated, but the main intuition remains. The incumbent's information rent would be reduced, as long as the public information is not perfect. One implication is that such public information disclosure regarding the control risk could increase the benefit from audit retendering due to the decrease in information rent.

\section{Concluding Remarks}

We analytically model a firm's audit engagement under two regimes: auditor retendering and mandatory auditor rotation. When comparing the two regimes, we find that the expected audit fee for the client firm under audit retendering is always higher than that under auditor rotation. While the two entrants always bid the expected audit cost under auditor rotation, both the incumbent and the entrant adopt the expected audit cost as the lower bound of their randomized bids under audit retendering. More importantly, in the presence of information asymmetry, the expected informativeness of audit reports under audit retendering is always higher than that under mandatory auditor rotation. Observing an auditor switch conveys additional information to investors. In equilibrium, the client firm favors audit retendering, when the benefit of audit efficiency exceeds 
the cost of higher audit fees.

We focus on audit retendering, a new provision in EU audit reforms. This feature distinguishes our paper from related studies on mandatory auditor rotation and auditor tenure. Our paper has direct implications for policy debates. Relative to mandatory auditor rotation, audit retendering can result in higher audit fees but more informative audit reports. This insight could be helpful to the PCAOB as it continues to evaluate mandatory auditor rotation and alternative regulation options in the U.S. 


\section{References}

[1] Antle, R. and B. Nalebuff. (2001). Conservatism And Auditor-Client Negotiations. Journal of Accounting Research 29: 31-54.

[2] Bamber, E.M., and V. Iyer. (2007). Auditors' identification with their clients and its effect on auditors' objectivity. Auditing: A Journal of Practice and Theory 26 (2): 1-24.

[3] Beattie, V., and Fearnley, S. (1998). Auditor changes and tendering: UK interview evidence. Accounting, Auditing \& Accountability Journal 11(1): 72-98.

[4] Cameron, M., A. Prencipe, and M. Trombetta. (2016). Mandatory audit firm rotation and audit quality. European Accounting Review 25 (1): 35-58.

[5] Carcello, J. V., and Nagy, A. L. (2004). Audit firm tenure and fraudulent financial reporting. Auditing: a journal of practice and theory 23(2): 55-69.

[6] Chan, D. (1999). "Low-balling" and efficiency in a two-period specialization model of auditing competition. Contemporary Accounting Research 16 (4): 609-642.

[7] Chan, D., and S. Pae. (1998). An analysis of the economic consequences of the proportionate liability rule. Contemporary Accounting Researchh 15: 457-480.

[8] Chan, D., and K. Wong. (2002). Scope of auditors' liability, audit quality, and capital investment. Review of Accounting Studies 7 (1): 97-122.

[9] Chen, C., Lin, C., and Y. Lin. (2008). Audit partner tenure, audit firm tenure, and discretionary accruals: Does long auditor tenure impair earnings quality? Contemporary Accounting Research 25: 415-445.

[10] Chi, W., Huang, H., Liao, Y., and Xie, H. (2009). Mandatory audit partner rotation, audit quality, and market perception: Evidence from Taiwan. Contemporary Accounting Research 26: $359-391$.

[11] DeAngelo, L. (1981). Auditor independence, "low-balling", and disclosure regulation. Journal of Accounting and Economics 3: 113-127. 
[12] DeFond, M. and J. Zhang. (2014). A review of archival auditing research. Journal of Accounting and Economics 58 (2-3): 275-326.

[13] Deng, M., Lu, T., Simunic, D. A., and Ye, M. (2014). Do joint audits improve or impair audit quality?. Journal of Accounting research 52(5): 1029-1060.

[14] Deis Jr, D. R., and Giroux, G. (1996). The effect of auditor changes on audit fees, audit hours, and audit quality. Journal of Accounting and Public policy 15(1): 55-76.

[15] Dordzhieva, A. (2018). Disciplining Role of Auditor Tenure and Mandatory Auditor Rotation. Working Paper. University of Texas.

[16] Dopuch, N., R.R. King. and R. Schwartz. (2001). An experimental investigation of retention and rotation requirements. Journal of Accounting Research 39: 93-117.

[17] Dye, R. A. (1991). Informationally Motivated Auditor Replacement. Journal of Accounting and Economics 14: 347-374.

[18] Dye, R. A. (1993). Auditing standards, legal liability, and auditor wealth. Journal of Political Economy 101 (5): 887-914.

[19] Dye, R. A. (1995). Incorporation and the Audit Market. Journal of Accounting and Economics 19: $75-114$.

[20] Engelbrecht-Wiggans, R., P. R. Milgrom, and R. J. Weber. (1983). Competitive Bidding and Proprietary Information. Journal of Mathematical Economics 11: 161-169.

[21] General Accounting Office (GAO). (2003). Public Accounting Firms: Required Study on the Potential Effects of Mandatory Audit Firm Rotation. GAO 04-216. General Accounting Office, Washington, DC.

[22] Gerakos, J. and C. Syverson. (2015). Competition in the Audit Market: Policy Implications. Journal of Accounting Research 53(4): 725-775.

[23] Ghosh, A., and D. Moon. (2005). Auditor tenure and perceptions of audit quality. The Accounting Review 80: 585-612. 
[24] Gigler, F. and M. Penno. (1995). Imperfect Competition In Audit Market And Its Effect On The Demand For Audit-Related Services. The Accounting Review 70 (2): 317-336.

[25] Gigler, F., and M. Penno. (1995). Imperfect Competition in Audit Markets and its Effect on the Demand for Audit-Related Services. The Accounting Review 70(2): 317-336.

[26] Hallman, N., A. Kartapanis, and J. Schmidt. (2018). The existence and effect of competition in the audit market: Evidence from the bidding process. Working paper, University of Texas at Austin.

[27] Harris, K., and S. Whisenant. (2012). Mandatory auditor rotation: An international investigation. Working paper, University of Houston.

[28] Hillegeist, S. A. (1999). Financial reporting and auditing under alternative damage apportionment rules. The Accounting Review 74 (3): 347-369.

Horton, J., Tsipouridou, M., and A. Wood. 2018. European Market Reaction to Audit Reforms. European Accounting Review 27 (5): 991-1023.

[29] Johnson, W.B., and T. Lys. (1990). The market for audit services: Evidence from voluntary auditor changes. Journal of Accounting and Economics 12 (1-3): 281-308.

[30] Johnson, V. E., Khurana, I. K., and Reynolds, J. K. (2002). Audit-firm tenure and the quality of financial reports. Contemporary accounting research 19(4): 637-660.

[31] Kanodia, C., and A. Mukherji. (1994). Audit Pricing, Low-Balling and Auditor Turnover: A Dynamic Analysis. The Accounting Review 69: 593-615.

[32] Kim, Y., and Park, M. S. (2006). Auditor changes and the pricing of seasoned equity offers. Accounting Horizons 20(4): 333-349.

[33] Kwon, S., Y. Lim, and R. Simnett. (2014). The effect of mandatory audit firm rotation on audit quality and audit fees: Empirical evidence from the Korean Audit Market. Auditing: A Journal of Theory and Practice 33 (4): 167-196.

[34] Laux, V., and P. Newman (2010). Auditor liabiltiy and client acceptance decisions. The Accounting Review 85: 261-285. 
[35] Lee, C.W. J., and Z. Gu. (1998). Low balling, legal liability and auditor independence. The Accounting Review 73(4):533-555.

[36] Lu, T. and H. Sapra (2009) Auditor Conservatism and Investment Efficiency. The Accounting Review 84(6): 1933-1958.

[37] Lu, T., and K. Sivaramakrishnan. (2009). Mandatory audit firm rotation: Fresh look versus poor knowledge. Journal of Accounting and Public Policy 28: 71-91.

[38] Lu, T., and K. Sivaramakrishnan (2010). Does mandatory audit firm rotation improve or impair corporate investment efficiency? Working Paper. University of Houston.

[39] Magee, R., and M. Tseng. (1990). Audit pricing and independence. The Accounting Review 65: $315-336$.

[40] Mansi, S., W. Maxwell, D. Miller. (2004). Does auditor quality and tenure matter to investors? Evidence from the bond market. Journal of Accounting Research 42 (4): 755-93.

[41] Milgrom, P. and R. Webber. (1982). The value of information in a sealed-bid auction. Journal of Mathematical Economics 10:105-114.

[42] Myers, J., L. Myers, and T. Omer. (2003). Exploring the term of auditor-client relationship and the quality of earnings: A case for mandatory auditor rotation? The Accounting Review 78 (3): 779-799.

[43] Morgan, J., and P. Stocken (1998). The Effects of Business Risk on Audit Pricing. Review of Accounting Studies 3: 365-385.

[44] PCAOB. (2004). An audit of internal control over financial reporting performed in conjunction with an audit of financial statements. PCAOB release No. 2004-001.

[45] Radhakrishnan, S. (1999). Investors' recovery friction and auditor liability rules. The Accounting Review 74: 225-240.

[46] PCAOB. (2004). An audit of internal control over financial reporting performed in conjunction with an audit of financial statements. PCAOB release No. 2004-001. 
[47] Reid, L, and J. Carcello. (2017). Investors reaction to the prospect of mandatory audit firm rotation. The Accounting Review 92 (1): 183-211.

[48] Ruiz-Barbadillo, E., Gomez-Aguilar, N., \& Carrera, N. (2009). Does mandatory audit firm rotation enhance auditor independence? Evidence from Spain. Auditing: A Journal of Practice \& Theory 28(2): 113-135.

[49] Shockley, R. A. (1981). Perceptions of auditors' independence: An empirical analysis. The Accounting Review 56: 785-800.

[50] Simon, D. T., and Francis, J. R. (1988). The effects of auditor change on audit fees: Tests of price cutting and price recovery. Accounting Review 255-269.

[51] Simunic, D. A. (1980). The Pricing of Audit Services: Theory and Evidence. Journal of Accounting Research 18: 161-190.

[52] Schwartz, R. (1997). Legal regimes, audit quality, and investment. The Accounting Review 72 : $385-406$.

[53] St. Pierre, K., and J. Anderson. (1984). An analysis of the factors associated with lawsuits against public accounts. The Accounting Review 59 (2): 242-263.

[54] Tysiac, K. (2014). Mandatory audit firm rotation rules published in EU. Journal of Accountancy. http://www.journalofaccountancy.com/news/2014/may/201410229.html.

[55] Wang, K. J., \& Tuttle, B. M. (2009). The impact of auditor rotation on auditor-client negotiation. Accounting, Organizations and Society 34: 222-243.

[56] Weiss, R. E., and Kalbers, L. P. (2008). Causes and consequences of auditor changes: A comparison of accelerated and non-accelerated filers. Available at SSRN 1270711. 


\section{Appendix I: Institution Background of Audit Tendering}

This section describes the current audit tender practice in the U.S. and European countries to provide a foundation for our model assumptions. Currently, any companies listed on the FTSE 100 and FTSE 250 indices must put their statutory audit services engagement out to tender no less than every 10 years. After the mandate became effective in 2015, the order has evolved into a professional standard of practice, and many companies have disclosed the details of their audit tender processes in their financial statements.

We summarize the audit tender process based on the final report of the "Statutory audit services for large companies market investigation." ${ }^{26}$ In its annual report, a company's audit committee announces their intention to commence a tender process for the appointment of an external auditor for the next fiscal year. The audit committee conducts a market assessment during the fiscal year, identifying qualified, independent public accounting firms. After the market assessment is completed, the audit committee invites qualified candidates to participate in a competitive bid and submit their proposals. After reviewing the proposals, the audit committee makes a recommendation to the board of directors whether a new external auditor will be appointed in the next fiscal year.

In their 2016 annual reports, a number of FTSE companies, including BHP Billiton Ltd, British Petroleum, Carnival Corporation \& PLC, GlaxoSmithKline (GSK), and Royal Dutch Shell PLC, disclosed that they tender audit engagements during the year. The following is an excerpt from GSK's 6-K filed on December 13, 2016 (page 2).

GSK today announces it intends to appoint Deloitte LLP ("Deloitte") as its auditor with effect from the accounting year ending 31 December 2018.

This follows a competitive audit tender process overseen by an Executive Steering Committee of GSK's Audit 63 Risk Committee chaired by Judy Lewent, which culminated in a recommendation that was approved by the Board.

\footnotetext{
${ }^{26}$ https://www.gov.uk/government/uploads/system/uploads/attachment_data/file/364145/Audit_Order.pdf. and https://www.frc.org.uk/getattachment/53c85956-d712-47d2-989f-2f8eff42be29/Audit-Tenders_notes-on-bestpractice-Feb-2017.pdf
} 
The current auditor PricewaterhouseCoopers LLP ("PwC") will continue in their role and undertake the audit of GSK until the year ending 31 December 2017, subject to reappointment by shareholders at GSK's 2017 Annual General Meeting. The appointment of Deloitte will be recommended to GSK's shareholders for approval at GSK's 2018 Annual General Meeting.

Judy Lewent, Chairman of GSK's Audit $\mathcal{E}$ Risk Committee, said: "I am pleased that having conducted a, thorough, open, and transparent process, the Audit $\mathcal{E}$ Risk Committee has concluded the audit tender. We would like to thank PwC for their significant contribution as GSK's auditor since the formation of GSK in 2001 and look forward to working with Deloitte in the future."

Voluntary audit tendering in the U.S follows similar practices as in the U.K. The following is an excerpt from the 2016 Proxy Statement of the PPL Corporation (page 77).

Pursuant to the policy of the Audit Committee to solicit competitive proposals for audit services from independent accounting firms at least once every ten years, the Audit Committee conducted a competitive selection process during 2015 to determine the company's independent registered public accounting firm for the audits of the consolidated financial statements as of and for the fiscal year ending December 31, 2016 of PPL and its subsidiary registrants. The Audit Committee invited several international public accounting firms to participate in this process, including Ernst $\mathcal{G}$ Young LLP, or EY. As a result of this process, on July 28, 2015, the Audit Committee approved the appointment of Deloitte as the company's independent registered public accounting firm for the fiscal year ending December 31, 2016. This action effectively dismissed EY as the company's independent registered public accounting firm and became effective upon $E Y^{\prime}$ 's completion of its procedures on the financial statements of PPL and its subsidiaries as of and for the fiscal year ended December 31, 2015 and the filing of the related Form 10-K, except with respect to audit and audit-related services pertaining to the fiscal year ended December 31, 2015, as required by PPL.

The audit reports of EY on the consolidated financial statements of PPL and its subsidiaries as of and for the fiscal years ended December 31, 2013 and 2014 did not contain any adverse opinion or disclaimer of opinion, nor were they qualified or modified as to uncertainty, audit scope or accounting principles. 


\section{Appendix II: Proofs}

\section{Proof of Lemma 1}

The proof proceeds with the following steps. First, we identify the bidding range as $\left[\bar{w}, w_{h}\right]$, where $\bar{w} \equiv \lambda w_{h}+(1-\lambda) w_{l}, w_{r} \equiv\left(1-q_{r}\right)(1-p) L+c_{r} \psi\left(q_{r}\right)$ and $w_{h}^{I} \equiv\left(1-q_{h}^{I}\right)(1-p) L+c_{h}^{I} \psi\left(q_{h}^{I}\right)$. The upper range $w_{h}$ represents the entrant auditor's expected total audit costs, including the expected audit liability $\left(1-q_{h}\right)(1-p) L$ and the cost of audit effort $c_{h} \psi\left(q_{h}\right)$. Denote $F_{O}$ by the entrant auditor's bid and $\left\{F_{I}^{l}, F_{I}^{h}\right\}$ by the incumbent auditor's bid when the control risk is low and high, respectively. It is clear that both entrant and incumbent auditors have the same bidding ranges. The incumbent auditor will not bid lower than $\bar{w}$, because it will decrease the fee revenue without increasing the probability of winning. In addition, the entrant can win the bid with certainty and make a positive profit by bidding below $\bar{w}$. Therefore, the lower bound is $\bar{w}$.

Second, the upper bidding bound is in the range of $\left[w_{h}^{I}, w_{h}\right]$, where $w_{h}^{I}$ is the incumbent's total audit cost and $w_{h}$ is the entrant's total audit cost. If the upper bound is lower than $w_{h}^{I}$, the incumbent will lose money from the audit engagement when the control risk is high. If the upper bound is higher than $w_{h}$, then two auditors can undercut each other's bid by a small amount and drive away the profit.

Third, within the biding range of the upper bound $\left[w_{h}^{I}, w_{h}\right]$, there exists a family of perverse equilibria that we will rule out using the trembling-hand refinement. If, given a high control risk, the incumbent bids above $w_{h}$ by a mistake with a probability $\lambda$, the entrant could then have a positive probability of winning the high-risk firm. In this scenario, the entrant would thus have an incentive to deviate, because the expected profit from the deviation is strictly positive. Therefore,

the incumbent will not bid above $w_{h}$. Moreover, the incumbent will not bid below $w_{h}^{I}$ because he will lose money. Therefore, the upper bound is in the range of $\left[w_{h}^{I}, w_{h}\right]$.

Fourth, within the bidding range of the upper bound $\left[w_{h}^{I}, w_{h}\right]$, the entrant will not bid any fee below $w_{h}$ with a pure strategy, because she expects to lose money with that strategy.

Lastly, when the control risk is high, the incumbent will bid $F_{I}^{h}=w_{h}$ with a pure strategy. We prove this result by a contradiction. Suppose that the incumbent does not always bid $w_{h}$ and bids 
$w_{h}^{\prime}$ in the range $w_{h}^{I} \leq w_{h}^{\prime}<w_{h}$ with a probability $\operatorname{Pr}\left(w_{h}^{\prime} \in\left[w_{h}^{I}, w_{h}\right)\right)>0$. In this case, if the entrant bids $F_{O} \in\left[w_{h}^{\prime}, w_{h}\right)$ with a probability $\gamma$ and $F_{O}=w_{h}$ with a probability $1-\gamma$, her expected payoff is

$\left.E\left[U_{O}\left(F_{O}\right)\right]=(1-\lambda) \operatorname{Pr}\left(F_{O}<F_{I}^{l}\right)\left(F_{O}-w_{l}\right)+\lambda\left[\gamma \operatorname{Pr}\left(F_{O}<F_{I}^{h}\right)\left(F_{O}-w_{h}\right)+(1-\gamma) \operatorname{Pr}\left(F_{O}<F_{I}^{h}\right)\left(F_{O}-w_{h}\right)\right)\right]$.

Note that in the equilibrium, the incumbent's bidding strategies must be non-decreasing. That is, when the control risk is low, the bidding for the low-control-risk $F_{I}^{l}$ must be lower than that for the high-control-risk $w_{h}^{\prime}\left(F_{I}^{l}<w_{h}^{\prime}\right)$. This suggests that $\operatorname{Pr}\left(F_{O}<F_{I}^{l}\right)$ in the first term is zero, because the entrant's bid is always higher than that of the incumbent. The second term is strictly negative because the entrant's bid is either lower than the cost $\left(F_{O}<w_{h}\right)$ or equals to the cost. Together, the entrant will lose money by biding in the range $\left[w_{h}^{I}, w_{h}\right)$. Suppose instead that the entrant always bids $F_{O}=w_{h}$, her expected payoff is zero

$$
\left.E\left[U_{O}(F)\right]=(1-\lambda) \operatorname{Pr}\left(F_{O}<F_{I}^{l}\right)\left(F_{O}-w_{l}\right)+\lambda \operatorname{Pr}\left(F<F_{I}^{h}\right)\left(F_{O}-w_{h}\right)\right)=0 .
$$

Anticipating the entrant's bidding strategy, the incumbent should bid $F_{I}^{h}=w_{h}$ with a pure strategy because he will win with the same probability, but earn more if he wins. This provides a contradiction. Taken together, the bidding range therefore is $\left[\bar{w}, w_{h}\right]$.

The entrant-auditor will adopt a randomized bidding strategy over the bidding range. For any pure-strategy bid $F_{O} \in\left[\bar{w}, w_{h}\right)$ by the entrant auditor, the incumbent auditor can respond with a strategy of bidding $F_{I}^{l}=F_{O}$ in the low-control-risk firm and $F_{I}^{l}=w_{h}$ in the high-control-risk firm. Given that the tie-breaking rule is in favor of the incumbent, the entrant auditor will only win in the high-cost firm and thus suffer a loss of $F_{O}-w_{h}$. This winner's curse will drive the entrant auditor to deviate from adopting this pure strategy in bidding. For a pure-strategy bid $F_{O}=w_{h}$ by the entrant auditor, the incumbent auditor will respond by bidding $F_{I}^{l}=w_{h}$ in the low-control-risk firm and $F_{I}^{h}=w_{h}$ in the high-control-risk firm. The entrant auditor will then have an incentive to deviate, because she can bid $F_{O} \in\left(\bar{w}, w_{h}\right)$, win the audit engagement all the time, and earn a profit of $F_{O}-\bar{w}$. Consequently, the entrant auditor will randomize her bids over the bidding range. 
Similarly, we can show that the incumbent auditor will also randomize his bids over the bidding range. When the control risk is high, the incumbent auditor will adopt a pure strategy, bidding $F_{I}^{h}=w_{h}$ all the time, because he has no incentive to deviate from this strategy.

In sum, at the equilibrium, the entrant auditor randomizes her bids according to $G_{O}(F)$, earning zero expected profit $E\left[U_{O}(F)\right]=0$ for any bid $F_{O} \in\left[\bar{w}, w_{h}\right]$. When the control risk is low, the incumbent auditor randomizes his bids according to $F_{I}^{l}$, earning a maximum information rent $E\left[U_{I}^{l}(F)\right]=\lambda\left(w_{h}-w_{l}\right)>0$ for any bid $F_{I}^{l} \in\left[\bar{w}, w_{h}\right]$. But when the control risk is high, the informed incumbent auditor always bid $w_{h}$, which includes the expected audit liability $\left(1-q_{h}^{I}\right)(1-p) L$ and the cost of audit effort $c_{h}^{I} \psi\left(q_{h}^{I}\right)$, earning a positive profit $E\left[U_{I}^{h}(F)\right]=w_{h}-w_{h}^{I}$. Because the expected profits are constant in these three cases, the bidders have no incentives to deviate from these equilibrium bidding strategies.

Lastly, we need to verify that $\left\{G_{O}(F), G_{I}^{l}(F), G_{I}^{h}(F)\right\}$ are equilibrium bidding strategies. The the uninformed auditor's expected payoff is

$$
E\left[U_{O}(F)\right]=\lambda\left(1-G_{I}^{h}(F)\right)\left(F-w_{h}\right)+(1-\lambda)\left(1-G_{I}^{l}(F)\right)\left(F-w_{l}\right),
$$

where $w_{r} \equiv\left(1-q_{r}\right)(1-p) L+c_{k} \psi\left(q_{r}\right)$. By contrast, when the control risk is high, the informed auditor's payoff is

$$
E\left[U_{I}^{h}(F) ; c_{h}^{I}\right]=F-w_{h}^{I}
$$

When the control risk is low, the informed auditor's payoff is

$$
E\left[U_{I}^{l}(F) ; c_{l}\right]=\left(1-G_{O}(F)\right)\left(F-w_{l}\right)=\left(\bar{w}-w_{l}\right)=\lambda\left(w_{h}-w_{l}\right) .
$$

Solving for $\left\{G_{O}(F), G_{I}^{l}(F), G_{I}^{h}(F)\right\}$ from these equations yields

$$
\begin{aligned}
G_{O}(F) & =\frac{F-\bar{w}}{F-w_{l}}, \\
G_{I}^{l}(F) & =\frac{F-\bar{w}}{(1-\lambda)\left(F-w_{l}\right)} .
\end{aligned}
$$

It follows that $g_{O}(F)$ and $g_{I}^{l}(F)$ represent the p.d.f of the entrant's and the incumbent's bidding 
strategy, respectively,

$$
\begin{aligned}
g_{O}(F) & =\frac{\lambda\left(w_{h}-w_{l}\right)}{\left(F-w_{l}\right)^{2}} \\
g_{I}^{l}(F) & =\frac{\lambda\left(w_{h}-w_{l}\right)}{(1-\lambda)\left(F-w_{l}\right)^{2}} .
\end{aligned}
$$

\section{Proof of Proposition 1}

First, we analyze the entrant auditor's expected audit fee,

$$
E\left[F_{O}\right]=\int_{\bar{w}}^{w_{h}} E\left[\hat{F}_{O}\right] g_{O}(F) d F
$$

where $g_{O}(F)$ represents the p.d.f of the entrant's bidding strategy and $E\left[\hat{F}_{O}\right]$ is the expected value of a winning bid for any $F_{O} \in\left[\bar{w}, w_{h}\right]$. The expected value of the entrant auditor's winning bid is

$$
\begin{aligned}
E\left[\hat{F}_{O}\right] & =\lambda \operatorname{Pr}\left(F_{I}^{h}>F\right) F+(1-\lambda) \operatorname{Pr}\left(F_{I}^{l}>F\right) F \\
& =\lambda F+(1-\lambda) F\left[1-\frac{F-\bar{w}}{(1-\lambda)\left(F-w_{l}\right)}\right] \\
& =\frac{F \lambda\left(w_{h}-w_{l}\right)}{F-w_{l}} .
\end{aligned}
$$

The p.d.f of the entrant's bidding strategy is

$$
g_{O}(F)=\frac{\lambda\left(w_{h}-w_{l}\right)}{\left(F-w_{l}\right)^{2}}
$$

Substituting $g_{O}(F)$ and $E\left[\hat{F}_{O}\right]$ into $E\left[F_{O}\right]$ yields

$$
\begin{aligned}
E\left[F_{O}\right] & =\int_{\bar{w}}^{w_{h}} E\left[\hat{F}_{O}\right] g_{O}(F) d F \\
& =\int_{\bar{w}}^{w_{h}} \frac{F \lambda^{2}\left(w_{h}-w_{l}\right)^{2}}{\left(F-w_{l}\right)^{3}} d F \\
& =-\left.\lambda^{2}\left(w_{h}-w_{l}\right)^{2} \frac{\left(2 F-w_{l}\right)}{2\left(F-w_{l}\right)^{2}}\right|_{\bar{w}} ^{w_{h}}, \\
& =\frac{1}{2}(1-\lambda)\left[2 \lambda w_{h}+(1-\lambda) w_{l}\right] .
\end{aligned}
$$

Second, we study the case in which the incumbent auditor privately observes a low control risk. 
In this case, the incumbent auditor's expected audit fee is

$$
E\left[F_{I}^{l}\right]=\int_{\bar{w}}^{w_{h}} E\left[\hat{F}_{I}^{l}\right] g_{I}^{l}(F) d F
$$

where $g_{I}^{l}(F)$ represents the p.d.f of the entrant's bidding strategy and $E\left[\hat{F}_{I}^{l}\right]$ is the expected value of a winning bid for any $F_{I}^{l} \in\left[\bar{w}, w_{h}\right]$. The expected value of a winning bid is

$$
E\left[\hat{F}_{I}^{l}\right]=\operatorname{Pr}\left(F_{O}>F\right) F=\left[1-\frac{F-\bar{w}}{F-w_{l}}\right] F .
$$

When the control risk is low $c_{l}$, the p.d.f of the incumbent's bidding strategy is

$$
g_{I}^{l}(F)=\frac{\lambda\left(w_{h}-w_{l}\right)}{(1-\lambda)\left(F-w_{l}\right)^{2}}
$$

Substituting $g_{O}(F)$ and $E\left[\hat{F}_{I}^{l}\right]$ into $E\left[F_{I}^{l}\right]$ yields

$$
\begin{aligned}
E\left[F_{I}^{l}\right] & =\int_{\bar{w}}^{w_{h}} F \frac{\bar{w}-w_{l}}{\left(F-w_{l}\right) w_{l}} \frac{\lambda\left(w_{h}-w_{l}\right)}{(1-\lambda)\left(F-w_{l}\right)^{2}} d F \\
& =-\left.\frac{\lambda^{2}\left(w_{h}-w_{l}\right)^{2}\left(2 F-w_{l}\right)}{2(1-\lambda)\left(F-w_{l}\right)^{2}}\right|_{\bar{w}} ^{w_{h}} \\
& =\lambda w_{h}+\frac{1}{2}(1-\lambda) w_{l} .
\end{aligned}
$$

Third, we examine the case in which the incumbent auditor privately observes a high control risk. When the control risk is high, the informed incumbent auditor bids $F=w_{h}$ all the time. Thus, the incumbent auditor's expected audit fee is

$$
\begin{aligned}
E\left[F_{I}^{h}\right] & =w_{h} \operatorname{Pr}\left(F_{O}=w_{h}\right)=w_{h}\left(1-G_{O}\left(w_{h}\right)\right) \\
& =\lambda w_{h} .
\end{aligned}
$$

Ex ante, the incumbent's expected audit fee is now given by

$$
\begin{aligned}
E\left[F_{I}\right] & =\lambda E\left[F_{I}^{h}\right]+(1-\lambda) E\left[F_{I}^{l}\right], \\
& =\lambda w_{h}+\frac{1}{2}(1-\lambda)^{2} w_{l} .
\end{aligned}
$$

Finally, we now calculate the difference in the expected audit fees between the incumbent and 
the entrant auditor as

$$
\Delta E[F] \equiv E\left[F_{I}\right]-E\left[F_{O}\right]=\lambda E\left[F_{I}^{h}\right]=\lambda^{2} w_{h}>0 .
$$

It follows that the difference $\Delta E[F]$ is increasing in $w_{h}$ and in $\lambda$. Recall that $w_{r} \equiv\left(1-q_{r}\right)(1-$ p) $L+c_{r} \psi\left(q_{r}\right)$. Substituting into $q_{r}^{*}=(1-p) L / c_{r}$, we obtain

$$
w_{h}=\frac{(1-p) L}{2 c_{h}}\left[2 c_{h}-(1-p) L\right]
$$

It follows that

$$
\frac{\partial w_{h}}{\partial c_{h}}=\frac{1}{2} \frac{L^{2}}{c_{h}^{2}}(p-1)^{2}>0
$$

suggesting that $\Delta E[F]$ increases in $c_{h}$.

\section{Proof of Proposition 2}

Denote by $\phi_{r}$ the probability of switching to the entrant auditor when the control risk is $r$. When the control risk is high, the probability that the entrant auditor wins the audit engagement is $\phi_{h}=G_{O}\left(w_{h}\right)=1-\lambda$. By contrast, when the control risk is low, the probability that the entrant auditor wins the audit engagement is

$$
\begin{aligned}
\phi_{l} & =\operatorname{Pr}\left(F_{O}<F_{I}^{l}\right)=\int_{\bar{w}}^{w_{h}} \operatorname{Pr}\left(F_{O}<F\right) \operatorname{Pr}\left(F_{I}^{l}=F\right) d F \\
& =\int_{\bar{w}}^{w_{h}} G_{O}(F) g_{I}^{l}(F) d F \\
& =\int_{\bar{w}}^{w_{h}}\left[\frac{F-\bar{w}}{F-w_{l}} \frac{\lambda\left(w_{h}-w_{l}\right)}{(1-\lambda)\left(F-w_{l}\right)^{2}}\right] d F \\
& =\frac{1-\lambda}{2}
\end{aligned}
$$

which is strictly lower than $\phi_{h}$. This suggests that $\phi_{h}>\phi_{l}$. Ex ante, without observing the control risk, the client firm expects to switch to the entrant auditor by the probability

$$
\phi \equiv \lambda \phi_{h}+(1-\lambda) \phi_{l}=\frac{1}{2}\left(1-\lambda^{2}\right)<\frac{1}{2} .
$$




\section{Proof of Proposition 3}

Before funding the capital $I$ to the firm, investors can observe (1) whether an audit switch has occurred, and (2) the auditor report issued by the winning auditor. Denote by $\left\{\alpha_{O}, \alpha_{I}\right\}$ the fraction of the project return when the audit report is issued by an entrant auditor and by an incumbent auditor, respectively. The investors' expected payoff is given by $V(\alpha, I, s)=\alpha_{s} \operatorname{Pr}(G \mid g, s) R-I=0$, where $s \in\{O, I\}$ is an indicator showing that the audit report is issued by the entrant auditor $(s=O)$ or by the incumbent auditor $(s=I)$. Denote by $\left\{\phi_{h}, \phi_{l}\right\}$ the probability of switching to an entrant auditor when the control risk is high and low, respectively. The investors' posterior beliefs are given by

$$
\operatorname{Pr}(G \mid g, O)=\frac{p\left[\lambda \phi_{h}+(1-\lambda) \phi_{l}\right]}{\lambda\left[p \phi_{h}+(1-p) \phi_{h}\left(1-q_{h}\right)\right]+(1-\lambda)\left[p \phi_{l}+(1-p) \phi_{l}\left(1-q_{l}\right)\right]},
$$

and

$$
\operatorname{Pr}(G \mid g, I)=\frac{p\left[\lambda\left(1-\phi_{h}\right)+(1-\lambda)\left(1-\phi_{l}\right)\right]}{\lambda\left[p\left(1-\phi_{h}\right)+(1-p)\left(1-\phi_{h}\right)\left(1-q_{h}^{I}\right)\right]+(1-\lambda)\left[p\left(1-\phi_{l}\right)+(1-p)\left(1-\phi_{l}\right)\left(1-q_{l}\right)\right]}
$$

where $q_{h}=(1-p) L / c_{h}, q_{h}^{I}=(1-p) L / c_{h}^{I}$ and $q_{l}>q_{h}^{I}>q_{h}$.

First, we consider a special case in which the incumbent auditor has no advantage $w_{h}^{I}=w_{h}$ (i.e., $c_{h}^{I}=c_{h}$ ) or thus $q_{h}^{I}=q_{h}$. In this case, as we showed previously, $\phi_{h}=1-\lambda$ and $\phi_{l}=(1-\lambda) / 2$. Given that, we can show that

$$
\begin{aligned}
\lim _{w_{h}^{I} \rightarrow w_{h}} \operatorname{Pr}(G \mid g, I) & =\frac{p\left[1+(2 p-1) \lambda^{2}\right]}{1+\lambda^{2}-2(1-p) \lambda^{2} q_{h}-(1-p)\left(1-\lambda^{2}\right) q_{l}} \\
\lim _{w_{h}^{I} \rightarrow w_{h}} \operatorname{Pr}(G \mid g, O) & =\frac{p[1+(2 p-1) \lambda]}{1+\lambda-2(1-p) \lambda q_{h}-(1-p)(1-\lambda) q_{l}} .
\end{aligned}
$$

It follows that given $w_{h}^{I}=w_{h}, \operatorname{Pr}(G \mid g, I)>\operatorname{Pr}(G \mid g, O)$.

Second, we consider the case where $w_{h}^{I}<w_{h}$, which suggests $c_{h}^{I}<c_{h}$. The effects of $c_{h}^{I}$ on the probability of switching $\operatorname{Pr}(G \mid g, I)$ can be characterized as follows:

$$
\frac{d \operatorname{Pr}(G \mid g, I)}{d k_{h}}=\underbrace{\frac{\partial \operatorname{Pr}(G \mid g, I)}{\partial \phi_{l}}}_{<0} \underbrace{\frac{\partial \phi_{l}}{\partial c_{h}^{I}}}_{>0}+\underbrace{\frac{\partial \operatorname{Pr}(G \mid g, I)}{\partial q_{h}^{I}} \frac{\partial q_{h}^{I}}{\partial c_{h}^{I}}}_{>0} .
$$


With some algebraic calculations, we can characterize that $\partial \operatorname{Pr}(G \mid g, I) / \partial \phi_{I}<0$ and $\partial \operatorname{Pr}(G \mid g, I) / \partial q_{h}^{I}>$ 0. Together with $\partial \phi_{l} / \partial c_{h}^{I}>0$ and $\partial q_{h}^{I} / \partial c_{h}^{I}<0$, it follows that $d \operatorname{Pr}(G \mid g, I) / d k_{h}<0$. That is, when $w_{h}^{I}$ is lower, $\operatorname{Pr}(G \mid g, I)$ is higher. Moreover, the effects of $c_{h}^{I}$ on the probability of switching $\operatorname{Pr}(G \mid g, I)$ are given by

$$
\frac{d \operatorname{Pr}(G \mid g, O)}{d k_{h}}=\underbrace{\frac{\partial \operatorname{Pr}(G \mid g, O)}{\partial \phi_{l}}}_{>0} \underbrace{\frac{\partial \phi_{l}}{\partial c_{h}^{I}}}_{>0}+\underbrace{\frac{\partial \operatorname{Pr}(G \mid g, O)}{\partial q_{h}^{I}} \frac{\partial q_{h}^{I}}{\partial c_{h}^{I}}}_{=0}>0 .
$$

This suggests that when $w_{h}^{I}$ is lower, $\operatorname{Pr}(G \mid g, O)$ is lower.

In sum, when the incumbent auditor has no advantage, $\operatorname{Pr}(G \mid g, I)>\operatorname{Pr}(G \mid g, O)$. When the incumbent auditor's knowledge advantage is higher (a lower $w_{h}^{I}$ ) $\operatorname{Pr}(G \mid g, I$ ) is strictly higher and $\operatorname{Pr}(G \mid g, O)$ is lower. Therefore, we prove that $\operatorname{Pr}(G \mid g, I)$ is strictly higher than $\operatorname{Pr}(G \mid g, O)$. Investors demand a fraction $\alpha_{s}^{*}$ of the project return $R$ so that they will break even for supplying capital $I$ : $\alpha_{I}^{*}=I / \operatorname{Pr}(G \mid g, I) R$ and $\alpha_{O}^{*}=I / \operatorname{Pr}(G \mid g, O) R$. Because $\operatorname{Pr}(G \mid g, I)>\operatorname{Pr}(G \mid g, O)$, it follows that $\alpha_{I}^{*}<\alpha_{O}^{*}$

\section{Proof of Corollaries 1, 2, and 3}

The auditor's optimal effort level is given by

$$
\frac{\partial U}{\partial q_{r}}=(1-p) L-c_{r} \psi^{\prime}\left(q_{r}\right)=0
$$

Thus, the optimal audit effort is $q_{r}^{*}=(1-p) L / c_{r}$. It is immediate that if the legal cost $L$ increases or the marginal cost $c_{r}$ decreases, the audit effort $q_{r}^{*}$ is higher. To ensure that $q_{r}^{*}<1$, we assume that the legal cost is not too large; that is, $L<c_{r} /(1-p)$. The auditor's expected payoff is

$$
\begin{aligned}
E\left[U\left(q, F_{m}\right)\right]= & \lambda\left[F_{m}^{*}-\left(1-q_{h}^{*}\right)(1-p) L-c_{h} \psi\left(q_{h}^{*}\right)\right] \\
& +(1-\lambda)\left[F_{m}^{*}-\left(1-q_{l}^{*}\right)(1-p) L-c_{l} \psi\left(q_{l}^{*}\right)\right]=0 .
\end{aligned}
$$


In equilibrium, the auditor expects to break even, so the audit fee is given by $F_{m}^{*}=\lambda w_{h}+(1-\lambda) w_{l}$, where $w_{r} \equiv\left(1-q_{r}\right)(1-p) L+c_{r} \psi\left(q_{r}\right)$. Substituting into $q_{r}^{*}=(1-p) L / c_{r}$, the audit fee is

$$
F_{m}^{*}=\frac{(1-p) L}{2 c_{h} c_{l}}\left\{2 c_{h} c_{l}-(1-p)\left[\lambda c_{l}+(1-\lambda) c_{h}\right] L\right\}
$$

Taking derivatives, we can show

$$
\begin{aligned}
\frac{\partial F_{m}^{*}}{\partial L} & =\frac{1-p}{c_{h} c_{l}}\left[c_{h} c_{l}-L(1-p)\left(c_{l} \lambda+c_{h}(1-\lambda)\right)\right]>0, \\
\frac{\partial F_{m}^{*}}{\partial c_{h}} & =\frac{\lambda(1-p)^{2} L^{2}}{2 c_{h}^{2}}>0, \\
\frac{\partial F_{m}^{*}}{\partial c_{l}} & =\frac{(1-\lambda)(1-p)^{2} L^{2}}{2 c_{l}^{2}}>0, \\
\frac{\partial F_{m}^{*}}{\partial \lambda} & =\frac{\left(c_{h}-c_{l}\right)(1-p)^{2} L^{2}}{2 c_{h} c_{l}}>0, \\
\frac{\partial F_{m}^{*}}{\partial p} & =-\frac{L}{c_{h} c_{l}}\left[c_{h} c_{l}-L(1-p)\left(c_{l} \lambda+c_{h}(1-\lambda)\right)\right]<0 .
\end{aligned}
$$

The investors' expected payoff is given by $V(\alpha, I)=\alpha \operatorname{Pr}(G \mid g) R-I=0$. Investors demand a fraction $\alpha^{*}$ of the project return $R$, so that they will be break even: $\alpha^{*}=\frac{I}{\operatorname{Pr}(G \mid g) R}<1$. Given the investors' posterior belief that

$$
\operatorname{Pr}(G \mid g)=\frac{p}{p+(1-p)\left[\lambda\left(1-q_{h}\right)+(1-\lambda)\left(1-q_{l}\right)\right]}
$$

it can be shown that

$$
\alpha^{*}=\frac{I}{p R}\left[1-(1-p)\left(\lambda q_{h}^{*}+(1-\lambda) q_{l}^{*}\right)\right]
$$

where the optimal audit effort $q_{r}^{*}=(1-p) L / c_{r}$. It is straightforward to obtain the following 
derivatives:

$$
\begin{aligned}
\frac{\partial \alpha^{*}}{\partial c_{h}} & =\frac{\lambda I(1-p)^{2} L}{p R c_{h}^{2}}>0, \\
\frac{\partial \alpha^{*}}{\partial c_{l}} & =\frac{(1-\lambda) I(1-p)^{2} L}{p R c_{l}^{2}}>0, \\
\frac{\partial \alpha^{*}}{\partial \lambda} & =\frac{I(1-p)^{2}\left(c_{h}-c_{l}\right) L}{p R c_{h} c_{l}}>0, \\
\frac{\partial \alpha^{*}}{\partial L} & =-\frac{I(1-p)^{2}\left(\lambda c_{l}+(1-\lambda) c_{h}\right)}{p R c_{h} c_{l}}<0 .
\end{aligned}
$$

\section{Proof of Proposition 4}

Denote by $F_{m}^{*}$ the expected audit fee under mandatory auditor rotation, which is given by $E\left[F_{m}^{*}\right]=$ $\lambda w_{h}+(1-\lambda) w_{l}=\bar{w}$. In contrast, the expected audit fee under audit retendering from the firm's perspective is

$$
E\left[F_{r}^{*}\right]=E\left[F_{O}\right]+E\left[F_{I}\right]=\bar{w}+\lambda(1-\lambda)\left(w_{h}-w_{l}\right)
$$

The difference of the audit fees is given by

$$
\Delta F \equiv E\left[F_{r}^{*}\right]-E\left[F_{m}^{*}\right]=\lambda(1-\lambda)\left(w_{h}-w_{l}\right),
$$

which presents the incumbent auditor's information rent.

\section{Proof of Proposition 5}

We now compare the informativeness of an audit report. First, because auditor rotation does not convey any information, the investors' posterior belief is given by

$$
\operatorname{Pr}(G \mid g)=\frac{p}{p+(1-p)\left[\lambda\left(1-q_{h}\right)+(1-\lambda)\left(1-q_{l}\right)\right]}
$$


Recall that when the audit report is issued by an entrant auditor, the investors' posterior beliefs are characterized by

$$
\begin{aligned}
\operatorname{Pr}(G \mid g, O) & =\frac{p\left[\lambda \phi_{h}+(1-\lambda) \phi_{l}\right]}{\lambda\left[p \phi_{h}+(1-p) \phi_{h}\left(1-q_{h}\right)\right]+(1-\lambda)\left[p \phi_{l}+(1-p) \phi_{l}\left(1-q_{l}\right)\right]} \\
& =\frac{p \cdot \phi}{p \cdot \phi+(1-p)\left[\lambda \phi_{h}\left(1-q_{h}\right)+(1-\lambda) \phi_{l}\left(1-q_{l}\right)\right]}, \\
& =\frac{p}{p+(1-p)\left[\frac{\phi_{h}}{\phi} \lambda\left(1-q_{h}\right)+\frac{\phi_{l}}{\phi}(1-\lambda)\left(1-q_{l}\right)\right]},
\end{aligned}
$$

where $\phi=\lambda \phi_{h}+(1-\lambda) \phi_{l}=\left(1-\lambda^{2}\right) / 2$ is the probability of switching to the entrant auditor, $\phi_{h}=1-\lambda, \phi_{l}=(1-\lambda) / 2$, and $\phi_{h}>\phi>\phi_{l}$. It follows immediately that $\operatorname{Pr}(G \mid g, O)<\operatorname{Pr}(G \mid g)$ because $1>q_{l}>q_{h}^{I}>q_{h}$. In contrast, when the audit report is issued by the incumbent auditor, the investors' posterior beliefs are characterized by

$$
\begin{aligned}
\operatorname{Pr}(G \mid g, I) & =\frac{p\left[\lambda\left(1-\phi_{h}\right)+(1-\lambda)\left(1-\phi_{l}\right)\right]}{\lambda\left[p\left(1-\phi_{h}\right)+(1-p)\left(1-\phi_{h}\right)\left(1-q_{h}^{I}\right)\right]+(1-\lambda)\left[p\left(1-\phi_{l}\right)+(1-p)\left(1-\phi_{l}\right)\left(1-q_{l}\right)\right]} \\
& =\frac{p(1-\phi)}{p(1-\phi)+(1-p)\left[\lambda\left(1-\phi_{h}\right)\left(1-q_{h}^{I}\right)+(1-\lambda)\left(1-\phi_{l}\right)\left(1-q_{l}\right)\right]}, \\
& =\frac{p}{p+(1-p)\left[\lambda \frac{1-\phi_{h}}{1-\phi}\left(1-q_{h}^{I}\right)+(1-\lambda) \frac{1-\phi_{l}}{1-\phi}\left(1-q_{l}\right)\right]}
\end{aligned}
$$

where $1-\phi=\lambda\left(1-\phi_{h}\right)+(1-\lambda)\left(1-\phi_{l}\right)$. Similarly, given that $\phi_{h}>\phi_{l}$ and $1>q_{l}>q_{h}^{I}>q_{h}$, it is shown that $\operatorname{Pr}(G \mid g, I)>\operatorname{Pr}(G \mid g)$.

Under audit retendering, the expected informativeness of the auditor's report is

$$
E[\operatorname{Pr}(G \mid g)]=\frac{p}{p+(1-p)\left\{\lambda\left[\phi_{h}\left(1-q_{h}\right)+\left(1-\phi_{h}\right)\left(1-q_{h}^{I}\right)\right]+(1-\lambda)\left(1-q_{l}\right)\right\}} .
$$

Note that if the incumbent does not have a knowledge advantage, then $q_{h}^{I} \rightarrow q_{h}$ and the expected informativeness $E[\operatorname{Pr}(G \mid g)]$ under audit retendering is the same as that under mandatory auditor rotation. However, as long as the incumbent has a knowledge advantage, then it follows that $\phi_{h}\left(1-q_{h}\right)+\left(1-\phi_{h}\right)\left(1-q_{h}^{I}\right)<\left(1-q_{h}\right)$, suggesting that $E[\operatorname{Pr}(G \mid g)]>\operatorname{Pr}(G \mid g)$. 


\section{Proof of Proposition 6 and Corollary 4}

Under the mandatory rotation regime, the client firm's expected payoff is

$$
\begin{aligned}
W_{m}\left(\alpha_{m}^{*}, F_{m}^{*}\right) & =p\left(1-\alpha_{m}^{*}\right) R-E\left[F_{m}^{*}\right] \\
& =p(R-I)-(1-p)\left[\lambda\left(1-q_{h}\right)+(1-\lambda)\left(1-q_{l}\right)\right] I-E\left[F_{m}^{*}\right]
\end{aligned}
$$

In contrast, the client's firm's expected payoff under the retendering regime,

$$
\begin{aligned}
W_{r}\left(\alpha_{r}^{*}, F_{r}^{*}\right) & =p\left(1-E\left[\alpha_{r}^{*}\right]\right) R-E\left[F_{r}^{*}\right] \\
& =p(R-I)-(1-p)\left\{\lambda\left[\phi_{h}\left(1-q_{h}\right)+\left(1-\phi_{h}\right)\left(1-q_{h}^{I}\right)\right]+(1-\lambda)\left(1-q_{l}\right)\right\} I-E\left[F_{r}^{*}\right],
\end{aligned}
$$

where $\phi_{h}=G_{O}\left(w_{h}\right)=1-\lambda$. Thus the difference of the firm's expected payoff between these two regimes is

$$
\begin{aligned}
\Delta W & \equiv W_{r}\left(\alpha_{r}^{*}, F_{r}^{*}\right)-W_{m}\left(\alpha_{m}^{*}, F_{m}^{*}\right), \\
& =(1-p)\left\{\lambda\left[\phi_{h}\left(1-q_{h}\right)+\left(1-\phi_{h}\right)\left(1-q_{h}^{I}\right)\right]-\lambda\left(1-q_{h}\right)\right\} I-\left(E\left[F_{r}^{*}\right]-E\left[F_{m}^{*}\right]\right), \\
& =\lambda\left[(1-p)\left(1-\phi_{h}\right)\left(q_{h}^{I}-q_{h}\right) I-(1-\lambda)\left(w_{h}-w_{l}\right)\right] .
\end{aligned}
$$

where the first term represents the investment loss due to a type-II error and the second term represents the incumbent auditor's information rent. Recall that $w_{r} \equiv\left(1-q_{r}\right)(1-p) L+c_{r} \psi\left(q_{r}\right)$ and $q_{r}^{*}=(1-p) L / c_{r}$. Substituting them into $\Delta W$, we can show that

$$
w_{h}-w_{l}=\frac{L^{2}(1-p)^{2}\left(c_{h}-c_{l}\right)}{2 c_{h} c_{l}}
$$

Given $\phi_{h}=1-\lambda$ and $q_{h}^{I}=(1-p) L / c_{h}^{I}$, it follows that

$$
\Delta W=\lambda L(1-p)^{2}\left[\frac{\lambda I\left(c_{h}-c_{h}^{I}\right)}{c_{h} c_{h}^{I}}-(1-\lambda) \frac{L\left(c_{h}-c_{l}\right)}{2 c_{h} c_{l}}\right] .
$$

It is straightforward to show that the firm's expected payoff is higher under audit retendering, ceteris paribus, when the information asymmetry is smaller (i.e., the difference $c_{h}$ and $c_{l}$ is smaller), the incumbent auditor's knowledge advantage is larger (i.e., a smaller $c_{h}^{I}$ ), and when the required 
investment $I$ is larger:

$$
\begin{aligned}
\frac{\partial \Delta W}{\partial I} & =\frac{\lambda^{2}(1-p)^{2}\left(c_{h}-c_{h}^{I}\right)}{c_{h} c_{h}^{I}}>0, \\
\frac{\partial \Delta W}{\partial c_{h}^{I}} & =-\frac{\lambda^{2}(1-p)^{2} L I}{\left(c_{h}^{I}\right)^{2}}<0 .
\end{aligned}
$$

When the control risk is more likely to be high (a high $\lambda$ ), the incumbent's information rent is smaller, suggesting that the client firm is more likely to benefit from audit retendering:

$$
\frac{\partial \Delta W}{\partial \lambda}=\frac{L(1-p)^{2}\left(c_{l} c_{h}^{I}(L-2 \lambda(2 I+L))+c_{h}\left(4 I \lambda c_{l}+(2 \lambda-1) L k_{h}\right)\right)}{2 c_{h} c_{l} c_{h}^{I}}>0 .
$$

The effect of the legal cost is not clear. Taking a partial derivative yields

$$
\frac{\partial \Delta W}{\partial L}=\frac{\lambda(1-p)^{2}\left(c_{l} c_{h}^{I}(L-\lambda(I+L))+c_{h}\left(I \lambda c_{l}-(1-\lambda) L k_{h}\right)\right)}{c_{h} c_{l} c_{h}^{I}} .
$$

It can be shown that there exists a threshold

$$
I^{*}=\frac{(1-\lambda) L\left(c_{h}-c_{l}\right) c_{h}^{I}}{\lambda c_{l}\left(c_{h}-c_{h}^{I}\right)}
$$

such that for $I>I^{*}, \partial \Delta W / \partial L>0$. 